\title{
Strawberry Polyphenol-Rich Fractions Can Mitigate Disorders in Gastrointestinal Tract and Liver Functions Caused by a High-Fructose Diet in Experimental Rats
}

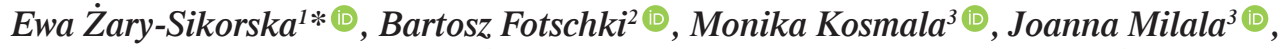 \\ Paulius Matusevicius ${ }^{4}$, Aleksandra Rawicka ${ }^{5}$, Jerzy Juśkiewicz ${ }^{2}{ }^{\circledR}$ \\ ${ }^{\prime}$ Department of Microbiology and Food Technology, Faculty of Agriculture and Biotechnology, \\ Bydgoszcz University of Science and Technology, Kaliskiego 7, 85-796 Bydgoszcz, Poland \\ ${ }^{2}$ Department of Biological Functions of Food, Institute of Animal Reproduction and Food Research \\ of the Polish Academy of Sciences, Tuwima 10, 10-748 Olsztyn, Poland \\ ${ }^{3}$ Institute of Food Technology and Analysis, Eódź University of Technology, Stefanowskiego 4/10, 90-924 Eódź, Poland \\ ${ }^{4}$ Department of Animal Nutrition, Lithuanian University of Health, Kaunas, Tilzes 18, LT-47181 Kaunas, Lithuania \\ ${ }^{5}$ Policlinico Veterinario Roma Sud, Ophthalmology, 00173 Rome, Italy
}

Key words: rat model, strawberry, bioactive compounds, anthocyanins, ellagitannins, gastrointestinal tract

In the current study, it was hypothesized that the addition of strawberry polyphenol-rich fractions to a high-fructose diet mitigates disorders in liver functions, lipid metabolism, and in the antioxidant and pro-inflammatory status of rats. Therefore, a fraction rich in ellagitannins and proanthocyanidins (EP), and a fraction containing compounds of both mentioned classes of polyphenols and additionally anthocyanins (EPA), in doses of 0.28 and $0.70 \mathrm{~g} / 100 \mathrm{~g}$, respectively, were added to a standard or a high-fructose diet administered to rats for six weeks. The EPA fraction was more beneficial in alleviating the consequences of consuming excess fructose in the diet than the EP fraction. Probably, that fraction containing considerable amounts of carbohydrates was more extensively metabolized by intestinal bacteria, which resulted in higher levels of cecal short chain fatty acids (SCFAs) as well as cecal and urinal ellagitannin metabolites. As a further consequence, diet supplementation with the EPA fraction caused more favorable changes in the levels of serum interleukin 6 and serum antioxidant capacity of water-soluble substances (ACW), in atherogenicity index $\lg (($ triglyceride/ high-density lipoprotein cholesterol), hepatic oxidized glutathione as well as reduced to oxidized glutathione ratio). Efforts should be made to develop strawberry polyphenol-rich preparations containing the preferred anthocyanins, which is, however, difficult due to the instability of this class of phenolic compounds during the technological process.

\section{INTRODUCTION}

Free fructose intake has increased significantly in the Western type diet over the past two decades due to the raised consumption of fructose-rich beverages. The widespread use of fructose corn syrup sweeteners in food production means that consumers ingest free fructose also in such products as corn flakes, sweet snacks, ready-made desserts, and sauces [Tappy \& Lê, 2010]. It has been shown that a diet overloaded with fructose causes adverse changes in the composition of the intestinal microflora by reducing the abundance of beneficial Bifidobacterium and Lactobacillus strains [Horne et al., 2020]. Additionally, unfavorable changes in the population of beneficial intestinal microbiota increase the level of lipopolysaccharides circulating in the blood, causing pro-inflammatory responses that precede the development of insulin resistance and obesity [Fuke et al., 2019]. Moreover, high levels of fructose in the diet are the main drivers of liver lipogenesis, by increasing the amount of microbial short-chain fatty acids - SCFAs (e.g. acetic acid), and contribute to the development of non-alcoholic fatty liver disease [Park et al., 2021]. Moreover, a fructose-rich diet contributes to weight gain, increased blood glucose levels, and adverse changes in the lipid profile, such as decreased high-density lipoprotein (HDL) / increased low-density lipoprotein (LDL) cholesterol levels and increased triglyceride content [Horne et al., 2020].

Strawberries (Fragaria ananassa) are commonly consumed both fresh and processed. They are a rich source of vitamins and bioactive compounds, such as folates, ascorbic acid, and phenolic compounds. The main class of phenolic compounds found in fresh strawberries is flavonoids, mainly anthocyanins (ACs), which account for over $75 \%$ of total phenolic compounds [Sirijan et al., 2020]. Their content can range from 150 to $600 \mathrm{mg} / \mathrm{kg}$ of fresh weight depending

\footnotetext{
* Corresponding Author:

E-mail: ezary@pbs.edu.pl (E. Żary-Sikorska)
} 
on plant genetic factors and growing conditions. Irrespective of the mentioned factors, which influence the total anthocyanin content in strawberries, the major anthocyanins of strawberries include pelargonidin 3-glucoside (89-95\%), followed by cyanidin 3-glucoside (3.9-10.6\%) [Sirijan et al., 2020]. In unripe strawberries, the flavonoids are mainly represented by proanthocyanidins (PAs), which are polymeric flavan-3-ols. The content of PAs in strawberries ranges from 0.539 to $1.632 \mathrm{mg} / \mathrm{g}$ of fresh weight [Sirijan et al., 2020]. Another group of strawberry phenolic compounds is ellagitannins (ETs), which are monomeric, oligomeric, and complex polymers of various combinations of gallic and hexahydroxydiphenic acid with glucose. Agrimoniin is indicated as the main ET both in the fresh fruits and particularly in pomace from the strawberry juice production [Nowicka et al., 2019]. Strawberry bioactive compounds, including ACs, Pas, and ETs, can play an important role in the prevention of civilization diseases caused by the Western type diet, like type 2 diabetes, obesity, cancer, cardiovascular diseases as well as oxidative stress, and pro-inflammatory and neurodegenerative conditions [Giampieri et al., 2012].

Consumption of fresh strawberry is seasonal, hence they are widely processed into juices or jams. It has been proved that strawberry processing reduces the content of bioactive compounds, including polyphenols. For example, during the industrial production of strawberry juice, most of the anthocyanins pervade to the juice, while majority of the ellagitannins remain in the pomace [Ertan et al., 2020]. The bioavailability of phenolic compounds is the basic factor determining their health-promoting activity. Studies have shown low ACs absorption and excretion with urine and feces after oral ingestion $(>2 \%)$, indicating that they undergo extensive biotransformation in the gastrointestinal tract. Thus, most anthocyanins are not absorbed in the upper small intestine, but pass to the colon, where they are metabolized by microflora [Aura et al., 2005]. In vitro studies with human fecal microflora have shown that the bacterial metabolism of anthocyanin glycosides is based on the cleavage of the sugar moiety and breakdown of the anthocyanidin heterocycle, resulting in the formation of aglycones followed by smaller phenolic acids [Aura et al., 2005]. A study by Hidalgo et al. [2012], in which the human colon microflora and anthocyanins were incubated under controlled conditions similar to those in the distal parts of the large intestine, showed $85 \%$ reduction of anthocyanins after $4 \mathrm{~h}$ of incubation. Moreover, the anthocyanins significantly increased the growth dynamics of the probiotic intestinal microflora such as Bifidobacterium and Lactobacillus-Enterococcus genera [Hidalgo et al., 2012]. Furthermore, anthocyanin extracts have exhibited antibacterial activity against pathogenic bacteria such as Salmonella enterica, Staphyloccocus aureus, Clostridium perfringens, or Helicobacter pylori [Bauza-Kaszewska et al., 2021].

Only about $5 \%$ of ETs are metabolized by the host's digestive enzymes, while most ETs are converted by colonic microbiota. ETs show different susceptibility to bacterial transformations, depending on many factors, including the chemical structure (polymerization degree) or the composition of the host microflora [Milala et al., 2017]. The microbial conversion of ETs and ellagic acid (EA) leads to the formation of a number of derivative compounds named urolithins (URs) and/or nasutins (NSs). Milala et al. [2017] found that NSs were the main metabolites in the rats' urine, feces, and blood serum after administration of experimental diet supplemented with strawberry ETs with a higher degree of polymerization. In the case of diet supplementation with ETs having a lower degree of polymerization, it was URs, then NSs. Selma et al. [2014] identified two strains of the genus Gordonibacter in human feces that were capable of converting EA to urolithin. Many studies have proven that ETs have a probiotic effect, promoting the growth of Lactobacillus and Bifidobacterium [Buzzini et al., 2008]. However, there are also contradictory reports supporting the hypothesis that ET metabolism is a counter-reaction of the intestinal microflora to the antibacterial activity of these compounds, as evidenced by the lack of trihydroxybenzoyl groups in the structure of metabolites, which determine the antibacterial activity of ETs [Buzzini et al., 2008].

In the present in vivo study, it was hypothesized that the dietary inclusion of strawberry bioactive compounds in the form of polyphenol-rich fractions would beneficially affect the intestinal and hepatic homeostasis as well as the blood redox and lipids status, especially in rats administered the high-fructose diet. Besides ETs and PAs, the authors investigated the effects of ACs, the most unstable phenolic compounds. Therefore, two types of dietary strawberry fractions obtained from fruit pomace (containing ETs and PAs - EP) and juice (containing ACs beside ETs and PAs - EPA) were investigated.

\section{MATERIALS AND METHODS}

\section{Preparation of the EP strawberry fraction}

Strawberry pomace was collected during strawberry juice production in the Alpex Company (Łęczeszyce, Poland). After drying at $70 \pm 2^{\circ} \mathrm{C}$ for $24 \mathrm{~h}$, the strawberry by-product was separated into a seed fraction and a seedless fraction (particle diameter of $0.5-1 \mathrm{~mm}$ and $1-3 \mathrm{~mm}$, respectively) using proper screens.

The seedless fraction was used to obtain the crude extracts. To this end, $20 \mathrm{~L}$ of $65 \%(\mathrm{v} / \mathrm{v})$ ethanol and $6 \mathrm{~kg}$ of the seedless fraction were put into a 30 -L volume extractor made of stainless steel at $20-25^{\circ} \mathrm{C}$. After $48 \mathrm{~h}$, the mixture was separated on a laboratory press resulting in an ethanol extract $(14.7 \mathrm{~L}$ ) and wet pomace $(10.2 \mathrm{~kg})$. The solvent was recovered by distillation, which gave $6 \mathrm{~L}$ of the polyphenol-rich residue, which contained $15 \%$ of ethanol. Then, a second step of extraction was conducted. The wet pomace from the first step of extraction and $15 \mathrm{~L}$ of $65 \%(\mathrm{v} / \mathrm{v})$ acetone were put into the extractor at $20^{\circ} \mathrm{C}$ for $24 \mathrm{~h}$. Then, $15 \mathrm{~L}$ of an acetone-ethanol extract was separated from $10 \mathrm{~kg}$ of pomace (wet weight) on a laboratory press. In the third step of extraction, the mixture of resulting pomace and $10 \mathrm{~L}$ of water was pressed after $1 \mathrm{~h}$ to result in $11 \mathrm{~kg}$ of wet pomace and $8 \mathrm{~L}$ of an acetone-ethanol-water extract. The solvents (acetone and ethanol) were evaporated from combined acetone extracts $(15 \mathrm{~L}$ and $8 \mathrm{~L})$ to give $6 \mathrm{~L}$ of the residue containing $\mathrm{ca}$. $15 \%$ ethanol. The 3 -step extraction was performed in duplicate and the extracts from both replicates were combined. Then, $12 \mathrm{~L}$ of the extract containing 
$600 \mathrm{~g}$ of dry matter were filtered on a cellulose filter and next purified by chromatography on an Amberlite XAD resin using $20 \mathrm{~L}$ column with $15 \mathrm{~L}$ of the adsorption bed. The process consisted in sorbent conditioning, adsorption of the polyphenols in the column bed with the flow rate of $1 \mathrm{BV} / \mathrm{h}(\mathrm{BV}-$ bed volume), removing ions and saccharides with the low molecular weight off the bed using $8 \%(v / v)$ ethanol with the flow rate of $2 \mathrm{BV}$, and gradual desorption of the fractions with opposite flow direction, at a flow rate of $0.2 \mathrm{BV} / \mathrm{h}$, and increasing ethanol concentration, i.e. by $30 \%(v / v)-1 \mathrm{BV}$, and by $55 \%$ $(v / v)$ - until the desorption has been completed. Fractions collected during the desorption were analyzed for polyphenol contents. The fractions which had similar compositions were mixed, concentrated, and freeze-dried. Taking into consideration the content of major polyphenols, the fraction with ETs as the dominant compounds and with a lower content of PAs and flavan-3-ols was selected for future in vivo experiments. The lyophilized product was placed in PET boxes and stored at $-4^{\circ} \mathrm{C}$ in the dark.

\section{Preparation of the EPA strawberry fraction}

The concentrated to total soluble solids of $62^{\circ} \mathrm{Bx}$, fresh, commercial strawberry juice (Alpex Company, Łęczeszyce, Poland) was used to obtain the EPA fraction. In the juice, which was used for fraction preparation, the content of pelargonidin 3 -glucoside was $1.1 \mathrm{~g} / \mathrm{kg}$ of the dry matter of the concentrated strawberry juice. After diluting the juice to $25^{\circ} \mathrm{Bx}$, it was purified on an Amberlite XAD resin. The column chromatography conditions were the same as those described above for the purification of strawberry pomace extract. The EPA fraction was eluted in the column using $30 \%(v / v)$ ethanol with a flow rate of $0.2 \mathrm{BV} / \mathrm{h}$. The collected fraction was concentrated and freeze-dried. The lyophilized product was placed in PET boxes and stored at $-4^{\circ} \mathrm{C}$ in the dark. Apart from ETs, PAs, and flavan-3-ols, the EPA strawberry fraction contained ACs.

\section{Proximate chemical composition of fractions}

The Association of Official Analytical Chemists (AOAC) methods $920.151,940.26,920.152,930.09$ were used to determine the dry matter, ash and lipid contents, respectively [AOAC, 2019]. The carbohydrate content was determined using the following formula: carbohydrate $=$ total solids - (lipid + ash $)$.

\section{Determination of polyphenol content in the fractions}

According to the procedure described by Sójka et al. [2013], the contents of ETs, EA, ACs, and flavonols were determined in the fractions using an HPLC system with a photodiode array detector (Knauer Smartline, Berlin, Germany) coupled with a Gemini C18 column $(110 \AA$, $250 \times 4.60 \mathrm{~mm}$, $5 \mu \mathrm{m}$; Phenomenex, Torrance, CA, USA). The standards were agrimoniin (obtained from the Institute of Food Technology and Analysis, Łódź, Poland), EA and pelargonidin 3-glucoside (Extrasynthese, Genay, France). Detection was performed for ETs at $250 \mathrm{~nm}$, for EA and flavonols at $360 \mathrm{~nm}$, and for ACs at $520 \mathrm{~nm}$. The column temperature was $35^{\circ} \mathrm{C}$, and the mobile phase flow rate was $1.25 \mathrm{~mL} / \mathrm{min}$. Mobile phase consisted of solvent $\mathrm{A}-0.05 \%(\mathrm{v} / \mathrm{v})$ phosphoric acid in water, and solvent $\mathrm{B}-0.05 \%(v / v)$ phosphoric acid in acetonitrile. Gradient was as follows: 0-5 min 4\% B; 5-12.5 min
4-15\% B; 12.5-42.5 min 15-40\% B; 42.5-51.8 min 40-50\% B; $51.8-53.4 \min 50-55 \% \mathrm{~B}$; and $53.4-55 \min 4 \% \mathrm{~B}$.

The determination of proanthocyanidins was performed after acid hydrolysis of the PAs with an excess of phloroglucinol according to the method of Kennedy \& Jones [2001]. The separation conditions have previously been described by Kosmala et al. [2015]. The following standards were used: (-)-epicatechin, (+)-catechin, (-)-epigallocatechin and their respective phloroglucinol adducts. The quantification was made based on the peak areas registered by the fluorescence detector (excitation wavelength: $278 \mathrm{~nm}$; emission wavelength: $360 \mathrm{~nm})$. The standard curves of (-)-epicatechin, $(+)$-catechin, and (-)-epicatechin-phloroglucinol adduct were used to quantify the breakdown products of the terminal units and extender units, respectively.

\section{Animal study}

The experiment was carried out using six experimental groups, each consisting of eight randomly assigned male Wistar rats, giving a total of 48 animals weighing $176 \pm 1.051 \mathrm{~g}$. The rats were housed individually in metabolic cages in a 12-h light: 12 -h dark cycle, at a stable temperature $\left(21-22^{\circ} \mathrm{C}\right)$, in a ventilated room (15 air changes per $\left.\mathrm{h}\right)$. They were used in accordance with the legal guidelines regulated by EU Directive (2010/63/EU). The experimental protocol was approved by the Local Institutional Animal Care and Use Committee (Olsztyn, Poland, approval no. 10/2018). During the 6-week experiment, the rats had free access to food (stored at $4^{\circ} \mathrm{C}$ in hermetic containers until the end of the experiment) and tap water (details are provided in Table 1). The diets were modifications of a casein diet for laboratory rodents recommended by the American Institute of Nutrition [Reeves, 1997]. All diets had equilibrated amounts of dietary protein, fiber, and polyphenols, if any, and were based on corn starch or on fructose. The corn starch diets were: corn starch $\left(\mathrm{C}_{\mathrm{S}}\right.$ group), corn starch and $\mathrm{EP}$ fraction ( $\mathrm{EP}_{\mathrm{S}}$ group), corn starch and EPA fraction $\left(\mathrm{EPA}_{\mathrm{S}}\right.$ group), whereas fructose diets were fructose $\left(\mathrm{C}_{\mathrm{F}}\right)$, fructose and EP fraction $\left(\mathrm{EP}_{\mathrm{F}}\right)$, fructose and EPA fraction $\left(\mathrm{EPA}_{\mathrm{F}}\right)$. Strawberry fractions were added to treatment diets at the expense of corn starch, i.e.: EP or EPA in doses of $0.28 \mathrm{~g}$ and $0.70 \mathrm{~g} / 100 \mathrm{~g}$ of diet, respectively. The calculation of experimental diets with the aid of the body surface area normalization method [Reagan-Shaw et al., 2008] and literature data for polyphenol content in the strawberry were used to represent a realistic amount of fresh strawberries consumed by humans. The composition of each group-specific diet is displayed in Table 1.

The body weight (BW) gain and individual feed consumption of rats were estimated. Rats were anesthetized with a ketamine/xylazine solution (100/10 mg per one kg BW). Before anesthesia, the rats were deprived of feed overnight (10-12 h).

\section{Sample collection and basic analyses}

\section{Blood analysis}

After a laparotomy, blood samples were collected from the caudal vein into 2.5 -mL heparinized test tubes, and serum was then obtained by solidification and low-speed centrifugation $\left(350 \times g, 10 \mathrm{~min}, 4^{\circ} \mathrm{C}\right)$. Serum samples were kept 
TABLE 1. Diet composition (g/100 g).

\begin{tabular}{|c|c|c|c|c|c|c|}
\hline & $\mathrm{C}_{\mathrm{S}}$ & $\mathrm{C}_{\mathrm{F}}$ & $\mathrm{EP}_{\mathrm{S}}$ & $\mathrm{EP}_{\mathrm{F}}$ & $\mathrm{EPA}_{\mathrm{s}}$ & $\mathrm{EPA}_{\mathrm{F}}$ \\
\hline Casein & 14.8 & 14.8 & 14.8 & 14.8 & 14.8 & 14.8 \\
\hline Cellulose $^{1}$ & 6 & 6 & 6 & 6 & 6 & 6 \\
\hline Rapeseed oil & 8 & 8 & 8 & 8 & 8 & 8 \\
\hline Mineral mix² & 1 & 1 & 1 & 1 & 1 & 1 \\
\hline Vitamin mix ${ }^{3}$ & 3.5 & 3.5 & 3.5 & 3.5 & 3.5 & 3.5 \\
\hline Choline chloride & 0.2 & 0.2 & 0.2 & 0.2 & 0.2 & 0.2 \\
\hline DL-methionine & 0.2 & 0.2 & 0.2 & 0.2 & 0.2 & 0.2 \\
\hline Cholesterol & 0.5 & 0.5 & 0.5 & 0.5 & 0.5 & 0.5 \\
\hline Extract EP & 0 & 0 & 0.28 & 0.28 & 0 & 0 \\
\hline Extract EPA & 0 & 0 & 0 & 0 & 0.70 & 0.70 \\
\hline Fructose & 0 & 65.0 & 0 & 65.0 & 0 & 65.0 \\
\hline Corn starch & 65.8 & 0.8 & 65.52 & 0.52 & 65.1 & 0.1 \\
\hline Calcd dietary polyphenols* & 0 & 0 & 0.199 & 0.199 & 0.198 & 0.198 \\
\hline Calcd dietary ellagitannins (mono:dimers)* & 0 & 0 & $0.121(55: 45)$ & $0.121(55: 45)$ & $0.096(54: 46)$ & $0.096(54: 46)$ \\
\hline Calcd dietary proanthocyanidins* & 0 & 0 & 0.069 & 0.069 & 0.071 & 0.071 \\
\hline Calcd dietary flavonols* & 0 & 0 & 0.009 & 0.009 & 0.013 & 0.013 \\
\hline Calcd dietary anthocyanins* & 0 & 0 & 0 & 0 & 0.018 & 0.018 \\
\hline Calcd dietary metabolized carbohydrates* & 0 & 0 & 0.05 & 0.05 & 0.46 & 0.46 \\
\hline
\end{tabular}

* from the composition of fraction with ellagitannins and proanthocyanidins (EP) or fraction with ellagitannins, proanthocyanidins and anthocyanins (EPA) (see Table 1).

${ }^{1} \alpha$-cellulose preparation was obtained from Sigma-Aldrich (No. C8002). ${ }^{2}$ AIN-93G [Reeves, 1997], g per kg mix: $357 \mathrm{~g}$ anhydrous calcium carbonate $(40.04 \% \mathrm{Ca}), 196 \mathrm{~g}$ monobasic potassium phosphate $(22.76 \% \mathrm{P}, 28.73 \% \mathrm{~K}), 70.78 \mathrm{~g}$ potassium citrate and tripotassium monohydrate $(36.16 \% \mathrm{~K})$, 74 g sodium chloride $(39.34 \% \mathrm{Na}, 60.66 \% \mathrm{Cl}), 46.6 \mathrm{~g}$ potassium sulfate $(44.87 \% \mathrm{~K}, 18.39 \% \mathrm{~S}), 24 \mathrm{~g}$ magnesium oxide $(60.32 \% \mathrm{Mg}), 6.06 \mathrm{~g}$ ferric citrate $(16.5 \% \mathrm{Fe}), 1.65 \mathrm{~g}$ zinc carbonate $(52.14 \% \mathrm{Zn}), 1.45 \mathrm{~g}$ sodium meta-silicate $99 \mathrm{H}_{2} \mathrm{O}(9.88 \% \mathrm{Si}), 0.63 \mathrm{~g}$ manganous carbonate $(47.79 \% \mathrm{Mn})$, $0.3 \mathrm{~g}$ cupric carbonate $(57.47 \% \mathrm{Cu}), 221.026 \mathrm{~g}$ powdered sucrose, and $0.275 \mathrm{~g}$ chromium potassium sulfate $\times 12 \mathrm{H}_{2} \mathrm{O}(10.42 \% \mathrm{Cr})$. The following components were added in $\mathrm{mg}$ per $\mathrm{kg}$ mix quantities: $81.5 \mathrm{mg}$ boric acid $(17.5 \% \mathrm{~B}), 63.5 \mathrm{mg}$ sodium fluoride $(45.24 \% \mathrm{~F}), 31.8 \mathrm{mg}$ nickel carbonate $(45 \%$ $\mathrm{Ni}), 17.4 \mathrm{mg}$ lithium chloride $(16.38 \% \mathrm{Li}), 10.25 \mathrm{mg}$ anhydrous sodium selenate $(41.79 \% \mathrm{Se}), 10 \mathrm{mg}$ potassium iodate $(59.3 \% \mathrm{I}), 7.95 \mathrm{mg}$ ammonium paramolybdate $\times 4 \mathrm{H}_{2} \mathrm{O}(54.34 \% \mathrm{Mo})$, and $6.6 \mathrm{mg}$ ammonium vanadate $(43.55 \% \mathrm{~V}) .{ }^{3} \mathrm{AIN}-93 \mathrm{G}$ [Reeves 1997], g per kg mix: $3.0 \mathrm{~g}$ nicotinic acid, $1.6 \mathrm{~g}$ Ca pantothenate, $0.7 \mathrm{~g}$ pyridoxine- $\mathrm{HCl}, 0.6 \mathrm{~g}$ thiamin- $\mathrm{HCl}, 974.655 \mathrm{~g}$ powdered sucrose, $0.6 \mathrm{~g}$ riboflavin, $0.2 \mathrm{~g}$ folic acid, $0.02 \mathrm{~g}$ biotin, $2.5 \mathrm{~g}$ vit. $\mathrm{B}_{12}$ (cyanocobalamin, $0.1 \%$ in mannitol). The following components were added in IU per g quantities: $15.0 \mathrm{IU}$ vit. E (all-rac- $\alpha$-tocopheryl acetate, 500 ), $0.8 \mathrm{IU}$ vit. A (all-trans-retinyl palmitate, 500000), $0.25 \mathrm{IU}$ vit. $\mathrm{D}_{3}$ (cholecalciferol, 400,000), and $0.075 \mathrm{IU}$ vit. $\mathrm{K}_{1}$ (phylloquinone). Diets: $\mathrm{C}_{\mathrm{S}}$, control diet with corn starch; $\mathrm{C}_{\mathrm{F}}$ control diet with $65 \%$ fructose; $\mathrm{EP}_{\mathrm{S}}$, corn starch diet with the $\mathrm{EP}$ strawberry fraction; $\mathrm{EP}_{\mathrm{F}}$ fructose diet with the $\mathrm{EP}$ fraction; $\mathrm{EPA}_{\mathrm{S}}$, corn starch diet with the EPA strawberry fraction; $\mathrm{EPA}_{\mathrm{F}}$ fructose diet with the EPA fraction.

frozen at $-70^{\circ} \mathrm{C}$ for further analysis. Blood samples were used to analyze total white blood cell count (WBC), granulocyte percentage (GRA), medium-sized cell percentage (MID), lymphocyte percentage (LYM), red blood cell count (RBC), hemoglobin (HGB), hematocrit (HCT), mean corpuscular hemoglobin $(\mathrm{MCH})$, mean corpuscular volume (MCV), mean corpuscular hemoglobin concentration (MCHC), red cell distribution width (RDWc), platelet count (PLT), platelet percentage (PCT), mean platelet volume (MPV), and platelet distribution width (PDWc) using the ABACUS Junior Vet hematological analyzer (Diatron MI PLC, Budapest, Hungary). The photochemiluminescence method was used to determine the serum antioxidant capacity of water-soluble and lipid-soluble substances (ACW and ACL, respectively). Particularly, a Photochem device and respective kits (ACW-Kit and ACL-Kit, Analytik Jena AG, Jena,
Germany), and ascorbic acid and Trolox as standards were used to determine ACW and ACL, respectively. The concentrations of HDL cholesterol (HDL), LDL cholesterol (LDL), total cholesterol (TC), and triglyceride (TG) fractions were determined using a biochemical analyzer (Pentra C200, Horiba, Tokyo, Japan). The same analyzer was used to determine serum levels of glucose, urea, and fructosamine (FRC) as well as the activity of aminotransferases: aspartate (AST) and alanine (ALT). The rat serum level of adiponectin was determined by enzyme immunoassay (Rat adiponectin ELISA Kit, Cusabio Biotech Co., Ltd., Wuhan, Hubei, China). Whereas, a validated rat insulin ELISA kit (Demeditec Diagnostics GmbH, Kiel, Germany) was used to determine the insulin concentration. The Thermo Scientific assays (Rockford, IL, USA) were used to determine the serum concentrations of interleukin 6 (IL-6) and tumor necrosis 
factor- $\alpha$ (TNF- $\alpha)$. The formula: homeostatic model assessment for insulin resistance (HOMA-IR) $=$ [fasting glycemia $(\mathrm{mM}) \times$ fasting insulinemia $(\mathrm{mU} / \mathrm{L}) / 22.5]$ was used to calculate the HOMA-IR index, while the following formulas: $\mathrm{AI}=\lg (\mathrm{TG} / \mathrm{HDL})$ and AII $=(\mathrm{TC}-\mathrm{HDL}) / \mathrm{HDL}$ were used to calculate the atherogenicity indexes of serum. Values for TG, TC, and HDL were expressed as mM.

\section{Small intestine and ceca evaluation}

Selected intestinal segments (small intestine, cecum, colon) were removed and weighed. The $\mathrm{pH}$ was immediately measured in the ileal, cecal, and colonic digesta, using a microelectrode and a $\mathrm{pH} / \mathrm{ION}$ meter (model 301; Hanna Instruments, Vila do Conde, Portugal). The mucosa from the second quarter of the small intestine was collected by scrapping with glass slides onto an iced glass plate. The mucosa samples were homogenized with four parts of a cold physiological saline $(v / w)$ and centrifuged for $10 \mathrm{~min}(10,000 \times g$, $4^{\circ} \mathrm{C}$ ). The obtained supernatant was stored at $-40^{\circ} \mathrm{C}$ until analysis. The procedure described by Jurgoński et al. [2013] was used to assay the activities of mucosal disaccharidases sucrase, maltase, and lactase, which were expressed as $\mu \mathrm{mol}$ of glucose liberated from the respective disaccharide per min per $g$ of protein. The Bradford method with bovine serum albumin as the standard was used to determine the mucosal protein content. In turn, contents of ammonia (microdiffusion method in Conway's dishes) and dry matter (at $105^{\circ} \mathrm{C}$ ) were determined in the fresh cecal digesta. Also, SCFAs were measured using a gas chromatograph (Shimadzu GC2010, Kyoto, Japan) and a capillary column (SGE BP21, $30 \mathrm{~m} \times 0.53 \mathrm{~mm}$; SGE Europe Ltd., Milton Keynes, UK) as described earlier by Kosmala et al. [2015]. The concentrations of cecal putrefactive SCFAs (PSCFAs) were calculated as the sum of iso-valeric, iso-butyric, and valeric acids. All SCFAs analyses were performed in duplicate. The mix of pure acetic, propionic, butyric, iso-butyric, iso-valeric, and valeric acids (individually obtained from Sigma, St. Louis, MO, USA) was used to plot a standard curve and then to calculate the contents of individual acids. To maintain the calibration, there was an additional set of pure acids included in each GC run of samples at five sample intervals. Cecal fermentation processes were also analyzed based on the activities of bacterial enzymes, like: $\alpha$ - and $\beta$-glucosidase, $\alpha$ - and $\beta$-galactosidase, and $\beta$-glucuronidase. According to the method described earlier by Fotschki et al. [2016], the activities of bacterial enzymes were measured by the rate of release of $p$-nitrophenol (PNP) or $o$-nitrophenol (ONP) from the respective nitrophenylglucosides. Intracellular (IEA) and extracellular enzyme activity (EEA) was also calculated. EEA was determined as the rate of enzyme release, expressed as a percentage of total enzyme activity (TEA), while IEA was calculated by comparing TEA with the activities of bacterial enzymes secreted into the intestinal environment, and expressed as $\mu$ mol product of PNP or ONP formed per $h$ per $g$ of digesta. The model curves for PNP and ONP (PNP or ONP standard solution in $100 \mathrm{mM}$ phosphate buffer $\mathrm{pH} 7.0,40 \mathrm{mg} / \mathrm{L}$ ) were used to prepare calculation formulas and derive suitable equations. All analyses were performed in duplicate.

\section{Heart, kidney, and liver evaluation}

Selected internal organs (heart, kidneys, liver) were removed and weighed. After storage at $-70^{\circ} \mathrm{C}$, they were determined for the content of thiobarbituric acid-reactive substances (TBARS) according to the spectrophotometrical procedure described by Botsoglou et al. [1994]. TBARS contents were expressed in $\mu \mathrm{g}$ malondialdehyde per $\mathrm{g}$ of tissue. Reduced glutathione (GSH) and oxidized glutathione (GSSG) contents were determined in stored liver samples using an enzymatic recycling method described by Rahman et al. [2006]. Liver lipids were extracted with the method of Folch et al. [1957]. After extraction, TC and TG contents were determined enzymatically using commercial kits (Cholesterol DST, Triglycerides DST, Alpha Diagnostics Ltd, Reinach, Switzerland). In accordance with the manufacturer's instructions, total RNA was extracted from liver samples using the TRI Reagent (Sigma-Aldrich, St. Louis, MO, USA). The quantity and quality of RNA were measured spectrophotometrically using a NanoDrop1000 (Thermo Fisher Scientific, Waltham, MA, USA) and agarose gel electrophoresis, respectively. Total RNA (500 ng) was used to synthesize cDNA using a High-Capacity cDNA Reverse Transcription Kit with RNase Inhibitor (Applied Biosystem, Waltham, MA, USA). Glyceraldehyde 3-phosphate dehydrogenase (GAPDH) was applied as a reference gene. The levels of peroxisome proliferator-activated receptor $\alpha$ (PPAR $\alpha$ ) and GAPDH mRNA expression were analyzed using Single Tube TaqManVR Gene Expression Assays (Life Technologies, Carlsbad, CA, USA) and a 7900HT Fast Real-Time PCR System. The amplification conditions were as follows: initial denaturation for $10 \mathrm{~min}$ at $95^{\circ} \mathrm{C}$; 40 cycles of $15 \mathrm{~s}$ at $95^{\circ} \mathrm{C}$, and $1 \mathrm{~min}$ at $60^{\circ} \mathrm{C}$. All samples were analyzed in duplicate, and each run included a standard curve, which was based on portions of combined liver RNA. The mRNA expression levels of PPAR $\alpha$ were normalized to GAPDH and multiplied by 10 .

\section{Quantification of ellagic acid and ET metabolites}

An HPLC system (Knauer Smartline system with a photodiode array detector) coupled with a Gemini C18 column $(110 \AA, 250 \times 4.60 \mathrm{~mm} ; 5 \mu \mathrm{m})$ was used to determine ellagic acid concentration in the cecal digesta after their hydrolysis with trifluoroacetic acid. Phase A was $0.05 \%(\mathrm{v} / \mathrm{v})$ phosphoric acid in water, phase B was $0.05 \%(v / v)$ phosphoric acid in $80 \%$ $(v / v)$ acetonitrile, the flow rate was $1.25 \mathrm{~mL} / \mathrm{min}$, the sample volume was $20 \mu \mathrm{L}$, and the temperature was $35^{\circ} \mathrm{C}$. The gradient was as follows: $0-10 \mathrm{~min} 10-25 \% \mathrm{~B}, 10-20 \mathrm{~min} 25-40 \% \mathrm{~B}$, 20-25 min 40-80\% B, 25-30 min 80\% B, 30-32 min 80-10\% B, and $32-40$ min $10 \%$ B. Ellagic acid was used as a standard, whereas the identification and quantification were performed at $360 \mathrm{~nm}$.

The concentrations of ET metabolites were determined in the cecal digesta and urine. A frozen sample of the digesta $(0.5-1 \mathrm{~g})$ was mixed with $2 \mathrm{~mL}$ of acetone, then sonicated for $10 \mathrm{~min}$, and centrifuged for $5 \mathrm{~min}(10,000 \times g)$. The supernatant was collected into a test tube. The procedure was repeated twice with $2 \mathrm{~mL}$ and $1 \mathrm{~mL}$ of $70 \%(\mathrm{v} / \mathrm{v})$ acetone. The extract was concentrated using a vacuum concentrator (ScanSpeed 40, Labogene, Allerød, Denmark). In the next step of the procedure, 
TABLE 2. Proximate chemical and polyphenol compositions of the strawberry fractions $(\mathrm{g} / 100 \mathrm{~g})$.

\begin{tabular}{|c|c|c|}
\hline & EP fraction ${ }^{1}$ & EPA fraction ${ }^{2}$ \\
\hline Dry matter & 93.3 & 99.1 \\
\hline Ash & 0.36 & 0.05 \\
\hline Lipids & 0.0 & 0.0 \\
\hline Metabolized carbohydrates ${ }^{3}$ & 21.0 & 70.5 \\
\hline including SDF & 0.0 & 0.0 \\
\hline Polyphenols (HPLC-DAD) & 71.8 & 28.6 \\
\hline Ellagic acid & 0.7 & 0.3 \\
\hline Ellagitannins & 43.2 & 13.7 \\
\hline monomers & 23.5 & 7.4 \\
\hline dimers & 19.7 & 6.4 \\
\hline Proanthocyanidins & 24.8 & 10.1 \\
\hline Flavonols & 3.2 & 1.9 \\
\hline Anthocyanins & 0.0 & 2.6 \\
\hline
\end{tabular}

${ }^{1}$ Fraction with ellagitannins and proanthocyanidins. ${ }^{2}$ Fraction with ellagitannins, proanthocyanidins and anthocyanins. ${ }^{3}$ Low-molecular carbohydrates and structural components of plant cell walls.

it was dissolved in methanol $(1 \mathrm{~mL})$. The HPLC system coupled with a Gemini C18 column was used to determine concentrations of ET metabolites. The same separation conditions were used as for ETs determination in dietary fractions. ET metabolites were identified by comparing their UV spectra with available literature data [Gonzales-Barrio et al., 2011] and additionally confirmed by the mass spectrometry (MS) method described by Fotschkiet al. [2018]. Urolithin-A, isolated from human urine in accordance with a semipreparative HPLC procedure previously described by Fotschki et al. [2016], was used as a standard for the quantification of ET metabolites.

\section{Statistical analysis}

The statistical analysis was performed using STATISTICA software, version 12.0 (StatSoft Corp., Krakow, Poland). The distribution of the data for normality was checked prior to further statistical analyses. A two-way analysis of variance (ANOVA) was used to determine the effect of the fraction addition (F; none, EP or EPA fraction) and the diet type ( $\mathrm{T}$; corn starch and fructose as the main dietary carbohydrate), and the interaction between these two factors $(\mathrm{F} \times \mathrm{T})$. The Duncan's post hoc test, which purpose is to determine differences among the respective treatment groups, was used when an interaction was significant $(p<0.05)$. The results were expressed as the means and pooled standard error of the mean (SEM).

\section{RESULTS AND DISCUSSION}

The chemical composition of strawberry fractions (EP and EPA), including the polyphenol composition, is presented in Table 2. The main differences between the EP and EPA strawberry fractions concern the qualitative and quantitative composition of the polyphenols. The EP fraction contained more polyphenols than the EPA fraction, $71.8 \mathrm{vs} .28 .6 \mathrm{~g} / 100 \mathrm{~g}$, respectively. On the other hand, the EPA fraction contained additionally ACs, apart from ETs, PAs and flavan-3-ols, also present in the EP fraction.

Feeding the rats for 4 weeks with high-fructose diets did not affect feed intake and body weight gain (Table 3). Tappy \& Lê [2010] demonstrated a significant effect of a fructose diet on the body weight of rodents over a long feeding period. The lack of weight gain may also be due to the thermogenic effect of fructose, previously noted in rodents [DeBosch et al., 2013] and in human studies [Mizobe et al., 2006]. The two-way ANOVA showed that, irrespective of fraction addition, the dietary fructose significantly increased small intestinal mass with contents, ileal digesta $\mathrm{pH}$ value, and the mucosal activity of maltase and lactase (Table 3). A significant fraction $\times$ diet type interaction revealed that the highest activity of sucrase in the jejunal mucosa followed the $\mathrm{C}_{\mathrm{F}}$ treatment $(p<0.05 v s$. all remaining groups). Additionally, the lowest sucrase activity was noted in the $\mathrm{C}_{\mathrm{S}}, \mathrm{EP}_{\mathrm{S}}$, and $\mathrm{EPA}_{\mathrm{S}}$ groups $(p<0.05 v$ s. all three fructose groups) (Table 3). Intestinal glucose transporter 5 (GLUT5) is remarkably responsive to its substrate fructose. Lower sucrase activity is associated with a lower intestinal content of fructose, which is an activator of intestinal GLUT5. However, a high fructose intake suppresses the activity of the GLUT5 transporter in colonocytes' membrane in the small intestine. Unabsorbed fructose is fermented by bacteria in the lower parts of the gastrointestinal tract, wherein the population of fructophilic bacteria and masses of colonic tissue and digesta (bulk effect) increase [Tappy \& Lê, 2010]. Anthocyanins are implied to stimulate the growth of Lactobacillus spp., Bifidobacterium spp., or the butyrate-producing $C$. coccoides - Eubacterium rectale [Hidalgo et al., 2012]. In the current study, strawberry fractions alleviated adverse changes in the ceca induced by a high fructose intake, including greater masses of the cecal digesta, which are related to the more intense fermentation in the colon. Moreover, the presence of anthocyanins in the EPA fraction positively influenced the concentration of ammonia in the cecal digesta of rats, regardless of diet type ( $p<0.05$ vs. $\mathrm{C}$ and EP; Table 4). Increased ammonia utilization is a beneficial change. An increase in ammonia levels is related to an increased incidence of colonic viral infections. Likewise, this bacterial protein degradation product can induce the growth of cancer cells and damage the intestinal epithelium [Hambly et al., 1997].

The two-way ANOVA analysis revealed that, regardless the fraction addition, the dietary application of $65 \%$ fructose caused a significant reduction in the cecal extracellular and total activities of bacterial $\alpha$ - and $\beta$-glucosidase, $\alpha$-and $\beta$-galactosidase in comparison to the rats fed diets based on corn starch (Table 5 and Table 6). Such a decrease was also noted in the case of cecal intracellular activity of the aforementioned bacterial enzymes, except $\alpha$-glucosidase. Irrespective of diet type, the dietary addition of both fractions significantly enhanced the activity of bacterial $\alpha$-glucosidase (extracellular and total), $\beta$-galactosidase (intracellular), and $\beta$-glucosidase (extracellular, intracellular, total) when 
TABLE 3. Growth parameters and small intestinal indices of rats fed experimental diets*.

\begin{tabular}{|c|c|c|c|c|c|c|c|c|c|}
\hline & \multirow{2}{*}{$\begin{array}{c}\text { Start BW } \\
(\mathrm{g})\end{array}$} & \multirow{2}{*}{$\begin{array}{c}\text { Final BW } \\
(\mathrm{g})\end{array}$} & \multirow{2}{*}{$\begin{array}{l}\text { Gain } \\
(\mathrm{g})\end{array}$} & \multirow{2}{*}{$\begin{array}{c}\text { Intake } \\
(\mathrm{g})\end{array}$} & \multicolumn{5}{|c|}{ Small intestine } \\
\hline & & & & & \begin{tabular}{|c|} 
Mass \\
$(\mathrm{g} / 100 \mathrm{~g} \mathrm{BW})^{1}$ \\
\end{tabular} & $\mathrm{pH}$ & $\begin{array}{c}\text { Sucrase } \\
(\mu \mathrm{mol} / \mathrm{min} / \mathrm{g} \text { protein })\end{array}$ & $\begin{array}{c}\text { Maltase } \\
(\mu \mathrm{mol} / \mathrm{min} / \mathrm{g} \text { protein })\end{array}$ & $\begin{array}{c}\text { Lactase } \\
(\mu \mathrm{mol} / \mathrm{min} / \mathrm{g} \text { protein })\end{array}$ \\
\hline \multicolumn{10}{|c|}{ Group $(\mathrm{n}=8)$} \\
\hline $\mathrm{C}_{\mathrm{s}}$ & 176 & 343 & 168 & 644 & 1.95 & 7.27 & $6.58^{c}$ & 42.8 & 1.87 \\
\hline $\mathrm{C}_{\mathrm{F}}$ & 176 & 347 & 172 & 621 & 2.15 & 7.64 & $10.6^{\mathrm{a}}$ & 52.9 & 2.92 \\
\hline $\mathrm{EP}_{\mathrm{S}}$ & 176 & 336 & 160 & 640 & 1.86 & 7.15 & $6.86^{\mathrm{c}}$ & 46.3 & 2.25 \\
\hline $\mathrm{EP}_{\mathrm{F}}$ & 175 & 329 & 154 & 640 & 2.16 & 7.45 & $8.77^{\mathrm{b}}$ & 51.9 & 2.63 \\
\hline $\mathrm{EPA}_{\mathrm{S}}$ & 176 & 343 & 167 & 655 & 2.01 & 7.18 & $6.58^{\mathrm{c}}$ & 46.3 & 2.38 \\
\hline $\mathrm{EPA}_{\mathrm{F}}$ & 175 & 337 & 161 & 655 & 2.13 & 7.37 & $8.24^{\mathrm{b}}$ & 48.6 & 2.90 \\
\hline SEM & 1.354 & 2.300 & 1.995 & 8.454 & 0.025 & 0.050 & 0.271 & 1.283 & 0.083 \\
\hline \multicolumn{10}{|c|}{ Fraction $(\mathrm{F})$} \\
\hline $\mathrm{C}$ (without) & 176 & 345 & 170 & 633 & 2.05 & 7.45 & 8.60 & 47.8 & 2.39 \\
\hline EP & 176 & 332 & 157 & 640 & 2.01 & 7.30 & 7.82 & 49.1 & 2.44 \\
\hline EPA & 176 & 341 & 165 & 657 & 2.07 & 7.29 & 7.29 & 48.0 & 2.63 \\
\hline$p$ value & 0.998 & 0.069 & 0.058 & 0.526 & 0.537 & 0.297 & 0.045 & 0.910 & 0.341 \\
\hline \multicolumn{10}{|c|}{ Diet type (T) } \\
\hline Starch & 176 & 341 & 165 & 648 & $1.94^{\mathrm{b}}$ & $7.21^{\mathrm{b}}$ & 6.73 & $45.5^{\mathrm{b}}$ & $2.16^{\mathrm{b}}$ \\
\hline FRU & 175 & 338 & 162 & 639 & $2.15^{\mathrm{a}}$ & $7.49^{\mathrm{a}}$ & 9.21 & $51.1^{\mathrm{a}}$ & $2.82^{\mathrm{a}}$ \\
\hline$p$ value & 0.851 & 0.429 & 0.428 & 0.608 & $* *$ & 0.005 & $* *$ & 0.031 & $* *$ \\
\hline \multicolumn{10}{|c|}{ Interaction $\mathrm{F} \times \mathrm{T}$} \\
\hline$p$ value & 0.989 & 0.473 & 0.411 & 0.851 & 0.231 & 0.626 & 0.012 & 0.371 & 0.120 \\
\hline
\end{tabular}

${ }^{*} \mathrm{C}_{\mathrm{S}}$, control diet with corn starch; $\mathrm{C}_{\mathrm{F}}$ control diet with $65 \%$ fructose $(\mathrm{FRU}) ; \mathrm{EP}_{\mathrm{S}}$, corn starch diet with the strawberry fraction with ellagitannins and proanthocyanidins $(\mathrm{EP}) ; \mathrm{EP}_{\mathrm{F}}$, fructose diet with the $\mathrm{EP}$ fraction; $\mathrm{EPA}_{\mathrm{s}}$, corn starch diet with the strawberry fraction with ellagitannins, proanthocyanidins and anthocyanins $(\mathrm{EPA}) ; \mathrm{EPA}_{\mathrm{F}}$ fructose diet with the EPA fraction.

a,b,c Mean values within a column with unlike superscript letters were shown to be significantly different $(p<0.05)$; differences among the groups $\mathrm{C}_{\mathrm{S}}$, $\mathrm{C}_{\mathrm{F}}, \mathrm{EP}_{\mathrm{S}}, \mathrm{EP}_{\mathrm{F}}, \mathrm{EPA}_{\mathrm{S}}$, and $\mathrm{EPA}_{\mathrm{F}}$ were indicated with superscripts only in the case of a statistically significant interaction $\mathrm{F} \times \mathrm{T}(p<0.05)$ and in that case the differences for the main factors $\mathrm{F}$ and $\mathrm{T}$ are not shown. ${ }^{* *} p<0.001$.

${ }^{1}$ Mass with contents; BW, body weight.

compared to the $\mathrm{C}$ treatment $(p<0.05)$ (Table 5 and Table 6 ). Additionally, the EP treatment was accompanied by the highest extracellular and total activity of $\beta$-galactosidase $(p<0.05 v s$. C and EPA). As indicated by a significant $\mathrm{F} \times \mathrm{T}$ interaction, the highest release rate of bacterial $\beta$-galactosidase into the cecal environment was determined in the $\mathrm{C}_{\mathrm{F}}$ rats while the lowest one in the $\mathrm{EPA}_{\mathrm{S}}$ and $\mathrm{EPA}_{\mathrm{F}}$ groups (in both cases $p<0.05$ vs. remaining treatments). The $\mathrm{C}_{\mathrm{F}}$ group had also the highest value of $\beta$-glucosidase release rate $(p<0.05$ vs. all other treatments except $\mathrm{EP}_{\mathrm{F}}$; see: significant $\mathrm{F} \times \mathrm{T}$ interaction). The $\mathrm{F} \times \mathrm{T}$ interaction revealed the highest extracellular as well as total activity of bacterial $\beta$-glucuronidase in the $\mathrm{C}_{\mathrm{F}}$ as well as $\mathrm{C}_{\mathrm{F}}$ and $\mathrm{EP}_{\mathrm{F}}$ groups, respectively $(p<0.05$ vs. all remaining groups; Table 6). The lowest $\beta$-glucuronidase activity (extracellular and total) was noted in the cecum of $\mathrm{EPA}_{\mathrm{F}}$ rats $(p<0.05 v$ s. all other groups). The intracellular $\beta$-glucuronidase activity was the highest in $\mathrm{EP}_{\mathrm{F}}$ rats compared to all other groups (see: significant $\mathrm{F} \times \mathrm{T}$ interaction). When comparing the three starch-fructose counterparts, only
$\mathrm{C}_{\mathrm{F}}$ group excelled the $\mathrm{C}_{\mathrm{S}}$ one when the calculated release rate of bacterial $\beta$-glucuronidase is considered (see $\mathrm{F} \times \mathrm{T}$ interaction). Excessive fructose consumption contributes to dysbiosis and adverse changes in the quantitative and qualitative composition of the intestinal microflora. There is mainly an increase in the number of Bacteroides and an increase of Firmicutes. These unfavorable changes in the Firmicute/Bacteroidetes ratio, a measure commonly associated with metabolic dysfunction and changes in enzymatic activity of microflora, occur with a high fructose diet [Horne et al., 2020]. A decrease in the enzymatic activities of intestinal bacteria results from this antibacterial effect of high-fructose diets on large intestine microflora. The decrease of the activity of galactosidases may intensify fermentation processes in the colon and underlay increased gas production and increased dyspeptic ailments in patients with irritable bowel syndrome [Hillilä et al., 2016]. Simultaneously, the high energy load of undigested fructose increases the extracellular activity of cecal bacterial enzymes, which, when released directly into the environment 
TABLE 4. Large intestine indices of rats fed experimental diets*.

\begin{tabular}{|c|c|c|c|c|c|c|c|c|}
\hline & \multicolumn{5}{|c|}{ Caecum } & \multicolumn{3}{|c|}{ Colon } \\
\hline & $\begin{array}{c}\text { Tissue } \\
(\mathrm{g} / 100 \mathrm{~g} \mathrm{BW})^{1} \\
\end{array}$ & $\begin{array}{c}\text { Digesta } \\
(\mathrm{g} / 100 \mathrm{~g} \mathrm{BW})^{1} \\
\end{array}$ & $\begin{array}{l}\mathrm{DM} \\
(\%)\end{array}$ & $\begin{array}{c}\mathrm{NH}_{3} \\
(\mathrm{mg} / \mathrm{g})\end{array}$ & $\mathrm{pH}$ & $\begin{array}{c}\text { Tissue } \\
(\mathrm{g} / 100 \mathrm{~g} \mathrm{BW})^{1} \\
\end{array}$ & $\begin{array}{c}\text { Digesta } \\
(\mathrm{g} / 100 \mathrm{~g} \mathrm{BW})^{1} \\
\end{array}$ & $\mathrm{pH}$ \\
\hline \multicolumn{9}{|c|}{ Group $(\mathrm{n}=8)$} \\
\hline $\mathrm{C}_{\mathrm{S}}$ & 0.163 & 0.518 & 24.5 & 0.239 & 7.39 & 0.293 & 0.324 & 7.65 \\
\hline $\mathrm{C}_{\mathrm{F}}$ & 0.171 & 0.654 & 25.4 & 0.255 & 7.46 & 0.340 & 0.518 & 7.66 \\
\hline $\mathrm{EP}_{\mathrm{S}}$ & 0.169 & 0.547 & 25.7 & 0.265 & 7.54 & 0.284 & 0.343 & 7.60 \\
\hline $\mathrm{EP}_{\mathrm{F}}$ & 0.173 & 0.551 & 25.7 & 0.253 & 7.63 & 0.283 & 0.383 & 7.70 \\
\hline $\mathrm{EPA}_{\mathrm{s}}$ & 0.177 & 0.546 & 26.3 & 0.218 & 7.31 & 0.271 & 0.360 & 7.69 \\
\hline $\mathrm{EPA}_{\mathrm{F}}$ & 0.174 & 0.578 & 26.9 & 0.209 & 7.48 & 0.300 & 0.381 & 7.72 \\
\hline SEM & 0.003 & 0.015 & 0.313 & 0.006 & 0.037 & 0.006 & 0.022 & 0.032 \\
\hline \multicolumn{9}{|c|}{ Fraction $(\mathrm{F})$} \\
\hline $\mathrm{C}$ (without) & 0.167 & 0.586 & 24.9 & $0.247^{\mathrm{a}}$ & 7.42 & $0.316^{\mathrm{a}}$ & 0.421 & 7.65 \\
\hline EP & 0.171 & 0.549 & 25.7 & $0.259^{\mathrm{a}}$ & 7.58 & $0.284^{b}$ & 0.363 & 7.65 \\
\hline EPA & 0.176 & 0.564 & 26.4 & $0.215^{\mathrm{b}}$ & 7.41 & $0.287^{b}$ & 0.372 & 7.70 \\
\hline$p$ value & 0.431 & 0.605 & 0.152 & 0.014 & 0.097 & 0.035 & 0.486 & 0.765 \\
\hline \multicolumn{9}{|c|}{ Diet type (T) } \\
\hline Starch & 0.170 & 0.538 & 25.4 & 0.241 & 7.42 & $0.284^{b}$ & $0.343^{\mathrm{b}}$ & 7.64 \\
\hline FRU & 0.173 & 0.593 & 26.0 & 0.239 & 7.52 & $0.308^{\mathrm{a}}$ & $0.427^{\mathrm{a}}$ & 7.69 \\
\hline$p$ value & 0.557 & 0.073 & 0.310 & 0.789 & 0.170 & 0.034 & 0.048 & 0.499 \\
\hline \multicolumn{9}{|c|}{ Interaction $\mathrm{F} \times \mathrm{T}$} \\
\hline$p$ value & 0.695 & 0.171 & 0.802 & 0.549 & 0.905 & 0.210 & 0.197 & 0.846 \\
\hline
\end{tabular}

${ }^{*} \mathrm{C}_{\mathrm{S}}$, control diet with corn starch; $\mathrm{C}_{\mathrm{F}}$ control diet with $65 \%$ fructose $(\mathrm{FRU}) ; \mathrm{EP}_{\mathrm{S}}$, corn starch diet with the strawberry fraction with ellagitannins and proanthocyanidins $(\mathrm{EP}) ; \mathrm{EP}_{\mathrm{F}}$ fructose diet with the $\mathrm{EP}$ fraction; $\mathrm{EPA}_{\mathrm{s}}$, corn starch diet with the strawberry fraction with ellagitannins, proanthocyanidins and anthocyanins $(\mathrm{EPA}) ; \mathrm{EPA}_{\mathrm{F}}$ fructose diet with the EPA fraction.

a,b,c Mean values within a column with unlike superscript letters were shown to be significantly different $(p<0.05)$; differences among the groups $\mathrm{C}_{\mathrm{S}}$, $\mathrm{C}_{\mathrm{F}} \mathrm{EP}_{\mathrm{S}}, \mathrm{EP}_{\mathrm{F}}, \mathrm{EPA}_{\mathrm{S}}$, and $\mathrm{EPA}_{\mathrm{F}}$ were indicated with superscripts only in the case of a statistically significant interaction $\mathrm{F} \times \mathrm{T}(p<0.05)$ and in that case the differences for the main factors $\mathrm{F}$ and $\mathrm{T}$ are not shown.

${ }^{1}$ mass with contents; BW, body weight.

of the large intestine, affect the rate of bacterial digestion of nutrients in lower parts of the digestive tract [Horne et al., 2020]. In both human [Bialonska et al., 2010] and animal studies [Molan et al., 2010], extracts of anthocyanins of various plant origins, have been found to increase the probiotic microflora and regulate the abundance of intestinal microflora, which corresponds to the research hypothesis that the addition of an anthocyanin-containing fraction (EPA) to a highfructose diet reduced the adverse changes in the enzymatic activity of the intestinal microflora, especially with regard to the potentially harmful $\beta$-glucuronidase. Furthermore, flavonoids favorably modified the activity of glucosidases and galactosidases in the cecal digesta of rats in other studies [Fotschki et al., 2016; Zduńczyk et al., 2006]. In the case of the EP fraction containing mainly ellagitannins, which are ascribed both antibacterial and growth-promoting properties of beneficial microflora, the decrease in the bacterial enzymatic activity was limited in the group fed the high-fructose diet, although the highest $\beta$-glucuronidase activity was noted in that group compared to all others groups (Table 6). Enhanced $\beta$-glucuronidase activity is claimed to be an initiator of colorectal cancer and a useful biomarker in disease diagnosis [Awolade et al., 2020].

The two-way ANOVA showed that, regardless of fraction addition, the fructose treatment lowered the cecal concentration of total SCFAs, including acetic acid concentration, in comparison to the starch dietary treatment (Table 7). Our study results indicate that fructose consumption influences the gut microflora and thus SCFA production through microbial fermentation. Irrespective of diet type, the EPA treatment caused a significant increase in the cecal concentration of isobutyric acid, valeric acid, total PSCFAs, and total SCFAs as well as in the cecal SCFA pool in comparison to the $\mathrm{C}$ and EP treatments $(p<0.05)$. The $\mathrm{F} \times \mathrm{T}$ interaction showed the lowest cecal propionic and butyric acid concentrations in the $\mathrm{C}_{\mathrm{F}}$ group ( $p<0.05 v s$. all other groups). In the case of butyric acid, its highest cecal concentration followed the ingestion of $\mathrm{EPA}_{\mathrm{S}}$ diet $(p<0.05$ vs. all other groups). The calculated 
TABLE 5. Activities of bacterial enzymes ( $\alpha$-glucosidase, $\alpha$ - and $\beta$-galactosidase) and their release rate into the cecal environment in rats*.

\begin{tabular}{|c|c|c|c|c|c|c|c|c|c|c|c|c|}
\hline & \multicolumn{4}{|c|}{$\alpha$-Glucosidase } & \multicolumn{4}{|c|}{$\alpha$-Galactosidase } & \multicolumn{4}{|c|}{$\beta$-Galactosidase } \\
\hline & 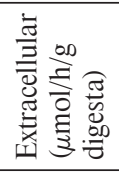 & 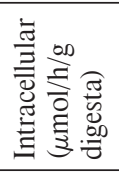 & 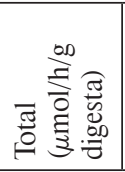 & 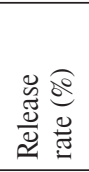 & 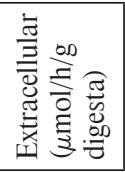 & 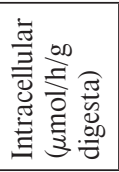 & 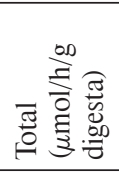 & 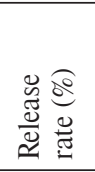 & 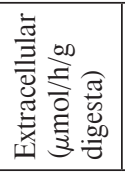 & 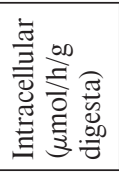 & 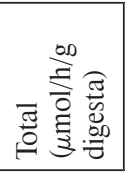 & 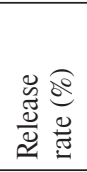 \\
\hline \multicolumn{13}{|c|}{ Group $(\mathrm{n}=8)$} \\
\hline $\mathrm{C}_{\mathrm{S}}$ & 10.3 & $2.45^{\mathrm{ab}}$ & 12.8 & 81.0 & 9.79 & 2.68 & 12.5 & 78.6 & 28.5 & 9.08 & 37.6 & $76.4^{\mathrm{b}}$ \\
\hline $\mathrm{C}_{\mathrm{F}}$ & 6.63 & $0.83^{\mathrm{c}}$ & 7.46 & 88.8 & 6.18 & 1.03 & 7.21 & 85.4 & 16.7 & 1.69 & 18.4 & $91.0^{\mathrm{a}}$ \\
\hline $\mathrm{EP}_{\mathrm{S}}$ & 12.2 & $2.74^{\mathrm{a}}$ & 15.0 & 82.0 & 8.35 & 3.56 & 1.9 & 70.5 & 30.9 & 12.3 & 43.1 & $72.2^{\mathrm{b}}$ \\
\hline $\mathrm{EP}_{\mathrm{F}}$ & 7.82 & $1.31^{\mathrm{bc}}$ & 9.13 & 85.6 & 7.28 & 2.07 & 9.34 & 79.1 & 26.1 & 7.72 & 33.9 & $78.0^{\mathrm{b}}$ \\
\hline $\mathrm{EPA}_{\mathrm{S}}$ & 12.6 & $1.96^{\mathrm{abc}}$ & 14.6 & 86.8 & 8.40 & 2.61 & 11.0 & 76.3 & 18.7 & 10.5 & 29.2 & $64.2^{\mathrm{c}}$ \\
\hline $\mathrm{EPA}_{\mathrm{F}}$ & 8.75 & $1.94^{\mathrm{abc}}$ & 10.7 & 83.7 & 6.47 & 2.33 & 8.80 & 73.9 & 14.8 & 7.93 & 22.7 & $65.2^{\mathrm{c}}$ \\
\hline SEM & 0.424 & 0.183 & 0.527 & 1.222 & 0.302 & 0.190 & 0.396 & 1.439 & 1.173 & 0.682 & 1.663 & 1.594 \\
\hline \multicolumn{13}{|c|}{ Fraction $(\mathrm{F})$} \\
\hline $\mathrm{C}$ (without) & $8.47^{\mathrm{b}}$ & 1.64 & $10.1^{\mathrm{b}}$ & 84.9 & 7.98 & 1.86 & 9.84 & 82.0 & $22.6^{\mathrm{b}}$ & $5.39^{\mathrm{b}}$ & $28.0^{\mathrm{b}}$ & 83.7 \\
\hline EP & $10.0^{\mathrm{a}}$ & 2.02 & $12.0^{\mathrm{a}}$ & 83.8 & 7.82 & 2.81 & 10.6 & 74.8 & $28.5^{\mathrm{a}}$ & $9.99^{\mathrm{a}}$ & $38.5^{\mathrm{a}}$ & 75.1 \\
\hline EPA & $10.7^{\mathrm{a}}$ & 1.80 & $12.5^{\mathrm{a}}$ & 85.3 & 7.68 & 2.39 & 10.1 & 76.4 & $17.3^{\mathrm{c}}$ & $9.37^{\mathrm{a}}$ & $26.6^{\mathrm{b}}$ & 65.2 \\
\hline$p$ value & 0.012 & 0.624 & 0.025 & 0.753 & 0.885 & 0.067 & 0.560 & 0.067 & $* *$ & 0.001 & $* *$ & $* *$ \\
\hline \multicolumn{13}{|c|}{ Diet type $(\mathrm{T})$} \\
\hline Starch & $11.7^{\mathrm{a}}$ & 2.29 & $14.0^{\mathrm{a}}$ & 83.8 & $9.01^{\mathrm{a}}$ & $2.90^{\mathrm{a}}$ & $11.9^{\mathrm{a}}$ & 76.0 & $26.4^{\mathrm{a}}$ & $10.7^{\mathrm{a}}$ & $37.1^{\mathrm{a}}$ & 71.3 \\
\hline FRU & $7.73^{\mathrm{b}}$ & 1.36 & $9.09^{\mathrm{b}}$ & 86.0 & $6.64^{\mathrm{b}}$ & $1.81^{\mathrm{b}}$ & $8.45^{\mathrm{b}}$ & 79.4 & $19.2^{\mathrm{b}}$ & $5.78^{\mathrm{b}}$ & $25.0^{\mathrm{b}}$ & 78.1 \\
\hline$p$ value & $* *$ & 0.007 & $* *$ & 0.370 & $* *$ & 0.002 & $* *$ & 0.190 & $* *$ & $* *$ & $* *$ & $* *$ \\
\hline \multicolumn{13}{|c|}{ Interaction $\mathrm{F} \times \mathrm{T}$} \\
\hline$p$ value & 0.876 & 0.044 & 0.449 & 0.123 & 0.122 & 0.138 & 0.132 & 0.080 & 0.132 & 0.216 & 0.113 & 0.012 \\
\hline
\end{tabular}

${ }^{*} \mathrm{C}_{\mathrm{S}}$, control diet with corn starch; $\mathrm{C}_{\mathrm{F}}$ control diet with $65 \%$ fructose $(\mathrm{FRU}) ; \mathrm{EP}_{\mathrm{S}}$, corn starch diet with the strawberry fraction with ellagitannins and proanthocyanidins $(\mathrm{EP}) ; \mathrm{EP}_{\mathrm{F}}$, fructose diet with the $\mathrm{EP}$ fraction; $\mathrm{EPA}_{\mathrm{s}}$, corn starch diet with the strawberry fraction with ellagitannins, proanthocyanidins and anthocyanins $(\mathrm{EPA}) ; \mathrm{EPA}_{\mathrm{F}}$ fructose diet with the EPA fraction.

a,b,c Mean values within a column with unlike superscript letters were shown to be significantly different $(p<0.05)$; differences among the groups $\mathrm{C}_{S}$, $\mathrm{C}_{\mathrm{F}}, \mathrm{EP}_{\mathrm{S}}, \mathrm{EP}_{\mathrm{F}} \mathrm{EPA}_{\mathrm{S}}$, and $\mathrm{EPA}_{\mathrm{F}}$ were indicated with superscripts only in the case of a statistically significant interaction $\mathrm{F} \times \mathrm{T}(p<0.05)$ and in that case the differences for the main factors $\mathrm{F}$ and $\mathrm{T}$ are not shown. ${ }^{* *} p<0.001$

Release rate, extracellular as \% of total activity.

SCFA profile values for acetic, propionic, and butyric acids were attributed to a significant $\mathrm{F} \times \mathrm{T}$ interaction. The highest percentage share of acetic acid $v s$. total SCFAs was in the $\mathrm{C}_{\mathrm{F}}$ group $\left(p<0.05 v\right.$ s. $\mathrm{C}_{\mathrm{S}}, \mathrm{EP}_{\mathrm{F}} \mathrm{EPA}_{\mathrm{S}}$ ), and that of propionic acid in the $\mathrm{EP}_{\mathrm{F}}$ group ( $p<0.05$ vs. other groups), and that of butyric acid in the $\mathrm{C}_{\mathrm{S}}$ and $\mathrm{EPA}_{\mathrm{S}}$ groups ( $p<0.05 \mathrm{v}$. remaining groups). Adverse changes in the production of three key SCFAs, namely butyric, acetic, and propionic acids, are considered risk factors of the development of such diseases as type 2 diabetes or non-alcoholic fatty liver disease (NAFLD) [Markowiak-Kopeć \& Śliżewska, 2020]. When using a high-fructose diet, a negative decrease in the cecal concentration of SCFAs as well as propionic and butyric acids was noted (Table 7). Butyric acid is the main source of energy for colonocytes, which influences the correctness of their division, as well as the overall health of the intestines, being a factor that protects against the development of inflammation and cancer of the colon wall
[Loke et al., 2020]. When supplementing diet with a fraction containing ETs and ACs, favorable modifications of SCFAs were concluded, regardless of whether the diet was based on fructose or starch (Table 7). Moreover, the highest concentration of butyric acid in relation to all groups was also determined in the EPAs group. Our previous studies have shown similar effects in experiments with Wistar rats using ET-rich extracts [Fotschki et al., 2014] and extracts of ETs and ACs from strawberries [Fotschki et al., 2016].

In the present study, an excess of fructose in the diet of experimental rats caused negative changes in the blood parameters of the antioxidant and proinflammatory status. Chronic excess of fructose in the diet promotes the multiplication of pro-inflammatory intestinal microflora that produces endotoxins and reduces the tightness of the intestinal barrier [Lu et al., 2020]. The $\mathrm{C}_{\mathrm{F}}$ group had the highest blood serum TNF $\alpha$ and IL-6 concentrations (Figure 1). Regardless 
TABLE 6. Activities of bacterial enzymes ( $\beta$-glucosidase $\beta$-glucuronidase) and the rate of their release into the cecal environment in rats".

\begin{tabular}{|c|c|c|c|c|c|c|c|c|}
\hline & \multicolumn{4}{|c|}{$\beta$-Glucosidase } & \multicolumn{4}{|c|}{$\beta$-Glucuronidase } \\
\hline & $\begin{array}{c}\text { Extracellular } \\
(\mu \mathrm{mol} / \mathrm{h} / \mathrm{g} \\
\text { digesta })\end{array}$ & $\begin{array}{c}\text { Intracellular } \\
(\mu \mathrm{mol} / \mathrm{h} / \mathrm{g} \\
\text { digesta })\end{array}$ & $\begin{array}{c}\text { Total } \\
(\mu \mathrm{mol} / \mathrm{h} / \mathrm{g} \\
\text { digesta }) \\
\end{array}$ & $\begin{array}{l}\text { Release } \\
\text { rate }(\%)\end{array}$ & $\begin{array}{c}\text { Extracellular } \\
(\mu \mathrm{mol} / \mathrm{h} / \mathrm{g} \\
\text { digesta })\end{array}$ & $\begin{array}{c}\text { Intracellular } \\
(\mu \mathrm{mol} / \mathrm{h} / \mathrm{g} \\
\text { digesta })\end{array}$ & $\begin{array}{c}\text { Total } \\
(\mu \mathrm{mol} / \mathrm{h} / \mathrm{g} \\
\text { digesta) } \\
\end{array}$ & $\begin{array}{l}\text { Release } \\
\text { rate }(\%)\end{array}$ \\
\hline \multicolumn{9}{|c|}{ Group $(n=8)$} \\
\hline $\mathrm{C}_{\mathrm{s}}$ & 1.93 & 0.87 & 2.80 & $70.4^{\mathrm{b}}$ & $12.2^{\mathrm{b}}$ & $5.60^{\mathrm{b}}$ & $17.8^{\mathrm{b}}$ & $69.4^{\mathrm{bc}}$ \\
\hline $\mathrm{C}_{\mathrm{F}}$ & 0.73 & 0.15 & 0.88 & $83.2^{\mathrm{a}}$ & $18.0^{\mathrm{a}}$ & $4.07^{\mathrm{b}}$ & $22.0^{\mathrm{a}}$ & $82.1^{\mathrm{a}}$ \\
\hline $\mathrm{EP}_{\mathrm{s}}$ & 2.39 & 0.77 & 3.15 & $74.3^{\mathrm{b}}$ & $12.8^{\mathrm{b}}$ & $4.64^{\mathrm{b}}$ & $17.4^{\mathrm{b}}$ & $72.6^{\mathrm{abc}}$ \\
\hline $\mathrm{EP}_{\mathrm{F}}$ & 1.82 & 0.57 & 2.39 & $77.2^{\mathrm{ab}}$ & $14.0^{\mathrm{b}}$ & $8.39^{\mathrm{a}}$ & $22.4^{\mathrm{a}}$ & $63.1^{\mathrm{c}}$ \\
\hline $\mathrm{EPA}_{\mathrm{s}}$ & 2.86 & 1.12 & 3.97 & $73.7^{\mathrm{b}}$ & $12.7^{\mathrm{b}}$ & $4.39^{\mathrm{b}}$ & $17.1^{\mathrm{b}}$ & $74.0^{\mathrm{ab}}$ \\
\hline $\mathrm{EPA}_{\mathrm{F}}$ & 2.14 & 0.85 & 2.99 & $72.1^{\mathrm{b}}$ & $8.77^{\mathrm{c}}$ & $3.90^{\mathrm{b}}$ & $12.7^{\mathrm{c}}$ & $68.9^{\mathrm{bc}}$ \\
\hline SEM & 0.131 & 0.078 & 0.187 & 1.555 & 0.560 & 0.370 & 0.721 & 1.492 \\
\hline \multicolumn{9}{|c|}{ Fraction $(\mathrm{F})$} \\
\hline $\mathrm{C}$ (without) & $1.33^{\mathrm{b}}$ & $0.508^{c}$ & $1.84^{\mathrm{b}}$ & 76.8 & 15.1 & 4.83 & 19.9 & 75.8 \\
\hline EP & $2.10^{\mathrm{a}}$ & $0.669^{b}$ & $2.77^{\mathrm{a}}$ & 75.8 & 13.4 & 6.51 & 19.9 & 67.8 \\
\hline EPA & $2.47^{\mathrm{a}}$ & $0.933^{\mathrm{a}}$ & $3.40^{\mathrm{a}}$ & 73.6 & 10.7 & 3.93 & 14.7 & 72.2 \\
\hline$p$ value & $* *$ & 0.045 & $* *$ & 0.697 & $* *$ & 0.006 & $* *$ & 0.053 \\
\hline \multicolumn{9}{|c|}{ Diet type (T) } \\
\hline Starch & $2.37^{\mathrm{a}}$ & $0.884^{\mathrm{a}}$ & $3.26^{\mathrm{a}}$ & 73.3 & 12.6 & 4.74 & 17.3 & 72.5 \\
\hline FRU & $1.56^{\mathrm{b}}$ & $0.523^{\mathrm{b}}$ & $2.08^{\mathrm{b}}$ & 77.5 & 13.6 & 5.45 & 19.0 & 71.4 \\
\hline$p$ value & $* *$ & 0.010 & $* *$ & 0.180 & 0.245 & 0.255 & 0.144 & 0.663 \\
\hline \multicolumn{9}{|c|}{ Interaction $\mathrm{F} \times \mathrm{T}$} \\
\hline$p$ value & 0.364 & 0.173 & 0.150 & 0.048 & $* *$ & 0.003 & 0.005 & 0.002 \\
\hline
\end{tabular}

${ }^{*} \mathrm{C}_{\mathrm{S}}$, control diet with corn starch; $\mathrm{C}_{\mathrm{F}}$ control diet with $65 \%$ fructose (FRU); $\mathrm{EP}_{\mathrm{S}}$, corn starch diet with the strawberry fraction with ellagitannins and proanthocyanidins $(\mathrm{EP}) ; \mathrm{EP}_{\mathrm{F}}$, fructose diet with the $\mathrm{EP}$ fraction; $\mathrm{EPA}_{\mathrm{s}}$, corn starch diet with the strawberry fraction with ellagitannins, proanthocyanidins and anthocyanins (EPA); $\mathrm{EPA}_{\mathrm{F}}$ fructose diet with the EPA fraction.

a,b,c Mean values within a column with unlike superscript letters were shown to be significantly different $(p<0.05)$; differences among the groups $\mathrm{C}_{\mathrm{S}}$, $\mathrm{C}_{\mathrm{F}} \mathrm{EP}_{\mathrm{S}}, \mathrm{EP}_{\mathrm{F}}, \mathrm{EPA}_{\mathrm{S}}$, and $\mathrm{EPA}_{\mathrm{F}}$ were indicated with superscripts only in the case of a statistically significant interaction $\mathrm{F} \times \mathrm{T}(p<0.05)$ and in that case the differences for the main factors $\mathrm{F}$ and $\mathrm{T}$ are not shown. ${ }^{* * *} p<0.001$.

Release rate, extracellular as \% of total activity.

of fraction addition, the dietary fructose treatment was associated with increased blood serum glucose, FRC, insulin, and calculated HOMA-IR value in comparison to the starch treatment (Table 8). Irrespective of diet type, the dietary addition of the EPA fraction caused a significant decrease in the blood serum IL-6 concentration $(p<0.05$ vs. C). In studies with strawberry preparations, their anti-inflammatory effect was proven by the enhancement of IL-10 (an anti-inflammatory cytokine) and the attenuation of IL-1 $\beta$, IL-6, and TNF- $\alpha$ (pro-inflammatory cytokines) [Liu \& Lin, 2013]. Strawberries are a source of anti-inflammatory ingredients, such as vitamin $\mathrm{C}$, anthocyanins, ellagitannins, and ellagic acid [Sirijan et al., 2020]. Nowicka et al. [2019] have demonstrated that the anti-inflammatory effect of strawberries is chiefly due to the presence of large amounts of pelargonidin 3-O-glucoside (P3G). The antiinflammatory effects of $\mathrm{P} 3 \mathrm{G}$ involve the nuclear factor kappa-light-chain-enhancer of activated B cells (NF-kB) and mitogen-activated protein kinase (MAPK) pathways. Hassimotto et al. [2013] pointed that the anthocyanin extract obtained from wild mulberry elicited anti-inflammatory effects by reducing the activity of myeloperoxidase (MPO), an enzyme that plays a key role in the pro-inflammatory process. In turn, Xu et al. [2018] observed a strong anti-inflammatory effect of urolithins $\mathrm{A}$ and $\mathrm{B}$ consisting in the inhibition of the activation of the NF- $\mathrm{BB}$, MAPK (p38 and Erk1/2), and Akt signaling pathways mediated by urolithin. In our previous study with strawberry extracts rich in ETs [Żary-Sikorska et al., 2020], we observed a decrease in TNF- $\alpha$, IL-1, and IL-6 rat blood levels.

The fructose dietary treatment significantly enhanced the blood serum concentration of TC, LDL, TG, and calculated values of the HDL profile, atherogenicity indexes $\lg (\mathrm{TG} /$ HDL) and (TC-HDL)/HDL, regardless of fraction addition (Table 8). The two-way ANOVA showed that both fractions added to a diet, irrespective of its type, caused a significant 
TABLE 7. Short chain fatty acid (SCFA) concentration ( $\mu \mathrm{mol} / \mathrm{g}$ digesta), total pool ( $\mu \mathrm{mol} / 100 \mathrm{~g}$ body weight) and profile (\% of total) in the cecal digesta.

\begin{tabular}{|c|c|c|c|c|c|c|c|c|c|c|c|c|}
\hline & \multicolumn{8}{|c|}{ SCFA concentration } & \multirow{2}{*}{$\begin{array}{c}\text { SCFA } \\
\text { pool }\end{array}$} & \multicolumn{3}{|c|}{ SCFA profile } \\
\hline & $\mathrm{C} 2$ & $\mathrm{C} 3$ & $\mathrm{C} 4 \mathrm{i}$ & $\mathrm{C} 4$ & C5i & $\mathrm{C} 5$ & PSCFA & SCFA & & $\mathrm{C} 2$ & $\mathrm{C} 3$ & $\mathrm{C} 4$ \\
\hline \multicolumn{13}{|c|}{ Group $(\mathrm{n}=8)$} \\
\hline $\mathrm{C}_{\mathrm{s}}$ & 92.9 & $22.0^{\mathrm{a}}$ & 2.17 & $15.8^{\mathrm{b}}$ & 2.35 & 2.16 & 6.68 & 137 & 70.2 & $67.5^{\mathrm{c}}$ & $16.1^{\mathrm{b}}$ & $11.5^{\mathrm{a}}$ \\
\hline $\mathrm{C}_{\mathrm{F}}$ & 73.7 & $14.1^{\mathrm{b}}$ & 1.86 & $7.10^{\mathrm{d}}$ & 2.53 & 2.29 & 6.68 & 102 & 66.7 & $72.4^{\mathrm{a}}$ & $14.0^{\mathrm{b}}$ & $7.00^{c}$ \\
\hline $\mathrm{EP}_{\mathrm{s}}$ & 98.1 & $21.3^{\mathrm{a}}$ & 2.07 & $12.7^{\mathrm{bc}}$ & 1.34 & 2.15 & 5.56 & 138 & 75.2 & $71.0^{\mathrm{ab}}$ & $15.7^{\mathrm{b}}$ & $9.16^{\mathrm{b}}$ \\
\hline $\mathrm{EP}_{\mathrm{F}}$ & 82.0 & $22.4^{\mathrm{a}}$ & 2.45 & $10.6^{c}$ & 1.55 & 2.19 & 6.20 & 121 & 66.6 & $67.6^{\mathrm{c}}$ & $18.6^{\mathrm{a}}$ & $8.58^{\mathrm{bc}}$ \\
\hline $\mathrm{EPA}_{\mathrm{s}}$ & 109 & $22.5^{\mathrm{a}}$ & 2.54 & $19.9^{\mathrm{a}}$ & 2.06 & 2.67 & 7.27 & 158 & 86.1 & $68.6^{\mathrm{bc}}$ & $14.2^{\mathrm{b}}$ & $12.5^{\mathrm{a}}$ \\
\hline $\mathrm{EPA}_{\mathrm{F}}$ & 99.9 & $21.6^{\mathrm{a}}$ & 2.97 & $13.0^{\mathrm{bc}}$ & 2.05 & 2.58 & 7.60 & 142 & 83.8 & $70.2^{\mathrm{ab}}$ & $15.4^{\mathrm{b}}$ & $9.08^{b}$ \\
\hline SEM & 2.667 & 0.575 & 0.102 & 0.742 & 0.094 & 0.066 & 0.180 & 3.637 & 2.603 & 0.495 & 0.362 & 0.374 \\
\hline \multicolumn{13}{|c|}{ Fraction (F) } \\
\hline C (without) & $83.3^{\mathrm{b}}$ & 18.0 & $2.01^{\mathrm{b}}$ & 11.4 & $2.44^{\mathrm{a}}$ & $2.23^{\mathrm{b}}$ & $6.68^{\mathrm{b}}$ & $119^{\mathrm{b}}$ & $68.4^{\mathrm{b}}$ & 69.9 & 15.0 & 9.27 \\
\hline EP & $90.0^{\mathrm{b}}$ & 21.8 & $2.26^{\mathrm{b}}$ & 11.6 & $1.45^{\mathrm{c}}$ & $2.17^{\mathrm{b}}$ & $5.88^{\mathrm{c}}$ & $127^{\mathrm{b}}$ & $70.9^{\mathrm{b}}$ & 69.3 & 17.2 & 8.87 \\
\hline EPA & $104^{\mathrm{a}}$ & 22.0 & $2.75^{\mathrm{a}}$ & 16.6 & $2.05^{\mathrm{b}}$ & $2.65^{\mathrm{a}}$ & $7.45^{\mathrm{a}}$ & $150^{\mathrm{a}}$ & $85.1^{\mathrm{a}}$ & 69.3 & 14.8 & 10.9 \\
\hline$p$ value & 0.002 & $* *$ & 0.010 & $* *$ & $* *$ & 0.007 & 0.002 & $* *$ & 0.023 & 0.809 & 0.005 & 0.012 \\
\hline \multicolumn{13}{|c|}{ Diet type (T) } \\
\hline Starch & $99.7^{\mathrm{a}}$ & 21.9 & 2.26 & 16.2 & 1.92 & 2.34 & 6.52 & $144^{\mathrm{a}}$ & 77.3 & 69.0 & 15.3 & 11.1 \\
\hline FRU & $85.2^{\mathrm{b}}$ & 19.3 & 2.43 & 10.2 & 2.04 & 2.36 & 6.82 & $122^{\mathrm{b}}$ & 72.4 & 70.1 & 16.0 & 8.22 \\
\hline$p$ value & 0.002 & 0.004 & 0.375 & $* *$ & 0.430 & 0.902 & 0.354 & $* *$ & 0.337 & 0.232 & 0.295 & $* *$ \\
\hline \multicolumn{13}{|c|}{ Interaction $\mathrm{F} \times \mathrm{T}$} \\
\hline$p$ value & 0.593 & $* *$ & 0.214 & 0.025 & 0.834 & 0.710 & 0.728 & 0.260 & 0.875 & 0.001 & 0.006 & 0.014 \\
\hline
\end{tabular}

${ }^{*} \mathrm{C}_{\mathrm{S}}$, control diet with corn starch; $\mathrm{C}_{\mathrm{F}}$ control diet with $65 \%$ fructose $(\mathrm{FRU}) ; \mathrm{EP}_{\mathrm{S}}$, corn starch diet with the strawberry fraction with ellagitannins and proanthocyanidins $(\mathrm{EP}) ; \mathrm{EP}_{\mathrm{F}}$, fructose diet with the $\mathrm{EP}$ fraction; $\mathrm{EPA}_{\mathrm{s}}$, corn starch diet with the strawberry fraction with ellagitannins, proanthocyanidins and anthocyanins $(\mathrm{EPA}) ; \mathrm{EPA}_{\mathrm{F}}$ fructose diet with the EPA fraction.

a,b,c Mean values within a column with unlike superscript letters were shown to be significantly different $(p<0.05)$; differences among the groups $\mathrm{C}_{\mathrm{S}}$, $\mathrm{C}_{\mathrm{F}}, \mathrm{EP}_{\mathrm{S}}, \mathrm{EP}_{\mathrm{F}}, \mathrm{EPA}_{\mathrm{S}}$, and $\mathrm{EPA}_{\mathrm{F}}$ were indicated with superscripts only in the case of a statistically significant interaction $\mathrm{F} \times \mathrm{T}(p<0.05)$ and in that case the differences for the main factors $\mathrm{F}$ and $\mathrm{T}$ are not shown. ${ }^{* *} p<0.001$.

PSCFA, putrefactive SCFA (the sum of iso-butyric, iso-valeric and valeric acids).

increase in the blood serum ACL (Figure 2), and a significant decrease in the blood serum TC and TG concentrations, and the (TC-HDL)/HDL index value ( $p<0.05$ vs. C). Additionally, regardless of diet type, the dietary EPA fraction significantly increased blood serum ACW and decreased the value of atherogenicity index $\lg (\mathrm{TG} / \mathrm{HDL})$, in comparison to the $\mathrm{C}$ treatment. According to the adopted hypothesis, the dietary application of EPA noticeably reduced unwanted changes in antioxidant parameters and blood lipid profile. In the study by Forbes-Hernández et al. [2017], the anthocyanin-enriched fraction from strawberries modified the parameters of antioxidant and lipid status in human hepatocellular carcinoma (HepG2) cells more favorably than the whole methanolic strawberry extract. The mechanism of the regulatory effect of polyphenols from berries on lipid metabolism was extensively investigated in the in vitro and in vivo studies. Prior et al [2009] indicated the anthocyanin extract of strawberries to be a viable preparation in preventing the development of dyslipidemia and obesity in mice. Moreover, in studies with obese mice, they demonstrated no anti-obesity effect or even increased obesity when whole strawberries were used in feeding. Aboonabi \& Aboonabi [2020] showed that the hypolipidemic effect of anthocyanins mighty be associated with upregulating mRNA expression of peroxisome proliferator-activated receptor- $\gamma$ (PPAR- $\gamma)$. In turn, Jarosławska et al. [2011] demonstrated the inhibition of pancreatic lipase activity by berry polyphenols, which significantly reduced the absorption of fat from the intestinal lumen. In our previous studies addressing the preparations of black carrots rich in anthocyanins [Żary-Sikorska et al., 2019] and preparations of strawberries containing ETs with various degrees of polymerization [Żary-Sikorska et al., 2020], a favorable modulation of the blood lipid profile of experimental rats was also noted. The metabolites of phenolic compounds that circulate in the blood and reach various target tissues are responsible for the hypolipidemic effects of phenolic compounds from 
TABLE 8. Biochemical indicators of the blood serum of rats fed experimental diets*.

\begin{tabular}{|c|c|c|c|c|c|c|c|c|c|c|c|}
\hline & \multirow{2}{*}{$\begin{array}{c}\mathrm{GL} \\
(\mathrm{mmol} / \mathrm{L})\end{array}$} & \multirow{2}{*}{$\begin{array}{c}\text { FRC } \\
(\mu \mathrm{mol} / \mathrm{L})\end{array}$} & \multirow{2}{*}{$\begin{array}{c}\text { Insulin } \\
(\mathrm{pmol} / \mathrm{L})\end{array}$} & \multirow{2}{*}{ HOMA-IR } & \multirow{2}{*}{$\begin{array}{c}\mathrm{TC} \\
(\mathrm{mmol} / \mathrm{L})\end{array}$} & \multirow{2}{*}{$\begin{array}{c}\mathrm{HDL} \\
(\mathrm{mmol} / \mathrm{L})\end{array}$} & \multirow{2}{*}{$\begin{array}{c}\mathrm{LDL} \\
(\mathrm{mmol} / \mathrm{L})\end{array}$} & \multirow{2}{*}{$\begin{array}{c}\text { HDL } \\
\text { profile } \\
(\% \text { of TC })\end{array}$} & \multirow{2}{*}{$\begin{array}{c}\mathrm{TG} \\
(\mathrm{mmol} / \mathrm{L})\end{array}$} & \multicolumn{2}{|c|}{ Atherogenicity index } \\
\hline & & & & & & & & & & $\begin{array}{c}\lg \\
(\mathrm{TG} / \mathrm{HDL}) \\
\end{array}$ & $\begin{array}{c}\text { (TC-HDL)/ } \\
\text { HDL }\end{array}$ \\
\hline \multicolumn{12}{|c|}{ Group $(n=8)$} \\
\hline $\mathrm{C}_{\mathrm{s}}$ & 9.70 & 160 & 28.9 & 1.78 & 2.28 & 0.631 & 0.449 & 27.9 & 2.16 & 2.62 & 0.521 \\
\hline $\mathrm{C}_{\mathrm{F}}$ & 14.0 & 173 & 38.7 & 3.48 & 3.41 & 0.675 & 0.651 & 19.9 & 3.41 & 4.06 & 0.694 \\
\hline $\mathrm{EP}_{\mathrm{S}}$ & 10.5 & 157 & 28.1 & 1.86 & 2.09 & 0.594 & 0.409 & 28.6 & 1.64 & 2.55 & 0.437 \\
\hline $\mathrm{EP}_{\mathrm{F}}$ & 13.0 & 168 & 39.4 & 3.27 & 3.09 & 0.641 & 0.605 & 21.8 & 2.88 & 4.07 & 0.655 \\
\hline $\mathrm{EPA}_{\mathrm{S}}$ & 10.3 & 159 & 28.8 & 1.89 & 2.18 & 0.640 & 0.469 & 29.5 & 1.94 & 2.48 & 0.486 \\
\hline $\mathrm{EPA}_{\mathrm{F}}$ & 13.3 & 163 & 34.8 & 2.98 & 2.99 & 0.705 & 0.591 & 24.1 & 2.95 & 3.37 & 0.621 \\
\hline SEM & 0.304 & 1.763 & 1.164 & 0.136 & 0.092 & 0.014 & 0.021 & 0.824 & 0.114 & 0.158 & 0.018 \\
\hline \multicolumn{12}{|c|}{ Fraction $(\mathrm{F})$} \\
\hline $\mathrm{C}$ (without) & 11.8 & 166 & 33.8 & 2.63 & $2.84^{\mathrm{a}}$ & 0.653 & 0.550 & 23.9 & $2.78^{\mathrm{a}}$ & $3.34^{\mathrm{a}}$ & $0.608^{\mathrm{a}}$ \\
\hline EP & 11.8 & 162 & 33.7 & 2.57 & $2.58^{\mathrm{b}}$ & 0.618 & 0.507 & 25.2 & $2.26^{\mathrm{b}}$ & $3.31^{\mathrm{ab}}$ & $0.546^{\mathrm{b}}$ \\
\hline EPA & 11.9 & 161 & 31.2 & 2.42 & $2.61^{\mathrm{b}}$ & 0.671 & 0.531 & 26.4 & $2.46^{\mathrm{b}}$ & $2.97^{\mathrm{b}}$ & $0.557^{\mathrm{b}}$ \\
\hline$p$ value & 0.971 & 0.437 & 0.491 & 0.666 & 0.048 & 0.328 & 0.602 & 0.344 & 0.009 & 0.045 & 0.031 \\
\hline \multicolumn{12}{|c|}{ Diet type (T) } \\
\hline Starch & $10.2^{\mathrm{b}}$ & $158^{\mathrm{b}}$ & $28.2^{\mathrm{b}}$ & $1.84^{\mathrm{b}}$ & $2.20^{\mathrm{b}}$ & 0.621 & $0.443^{b}$ & $28.4^{\mathrm{a}}$ & $1.92^{\mathrm{b}}$ & $2.58^{\mathrm{b}}$ & $0.484^{\mathrm{b}}$ \\
\hline FRU & $13.4^{\mathrm{a}}$ & $168^{\mathrm{a}}$ & $37.6^{\mathrm{a}}$ & $3.24^{\mathrm{a}}$ & $3.16^{\mathrm{a}}$ & 0.674 & $0.616^{\mathrm{a}}$ & $21.9^{\mathrm{b}}$ & $3.08^{\mathrm{a}}$ & $3.83^{\mathrm{a}}$ & $0.657^{\mathrm{a}}$ \\
\hline$p$ value & $* *$ & 0.008 & $* *$ & $* *$ & $* *$ & 0.078 & $* *$ & $* *$ & $* *$ & $* *$ & $* *$ \\
\hline \multicolumn{12}{|c|}{ Interaction $\mathrm{F} \times \mathrm{T}$} \\
\hline$p$ value & 0.155 & 0.553 & 0.696 & 0.486 & 0.448 & 0.939 & 0.577 & 0.576 & 0.705 & 0.173 & 0.378 \\
\hline
\end{tabular}

${ }^{*} \mathrm{C}_{\mathrm{S}}$, control diet with corn starch; $\mathrm{C}_{\mathrm{F}}$ control diet with $65 \%$ fructose $(\mathrm{FRU}) ; \mathrm{EP}_{\mathrm{S}}$, corn starch diet with the strawberry fraction with ellagitannins and proanthocyanidins $(\mathrm{EP}) ; \mathrm{EP}_{\mathrm{F}}$ fructose diet with the $\mathrm{EP}$ fraction; $\mathrm{EPA}_{\mathrm{S}}$, corn starch diet with the strawberry fraction with ellagitannins, proanthocyanidins and anthocyanins $(\mathrm{EPA}) ; \mathrm{EPA}_{\mathrm{F}}$ fructose diet with the EPA fraction.

a,b,c Mean values within a column with unlike superscript letters were shown to be significantly different $(p<0.05)$; differences among the groups $\mathrm{C}_{\mathrm{S}}$, $\mathrm{C}_{\mathrm{F}}, \mathrm{EP}_{\mathrm{S}}, \mathrm{EP}_{\mathrm{F}}, \mathrm{EPA}_{\mathrm{S}}$, and $\mathrm{EPA}_{\mathrm{F}}$ were indicated with superscripts only in the case of a statistically significant interaction $\mathrm{F} \times \mathrm{T}(p<0.05)$ and in that case the differences for the main factors $\mathrm{F}$ and $\mathrm{T}$ are not shown. ${ }^{* *} p<0.001$. GL, glucose; FCR, fructosamine; HOMA-IR, homeostatic model assessment for insulin resistance [fasting glycemia $(\mathrm{mmol} / \mathrm{L}) \times$ fasting insulinemia $(\mathrm{mU} / \mathrm{L}) / 22.5$ ]; TC, total cholesterol; HDL, high-density lipoprotein; LDL, low-density lipoprotein; TG, triglycerides.

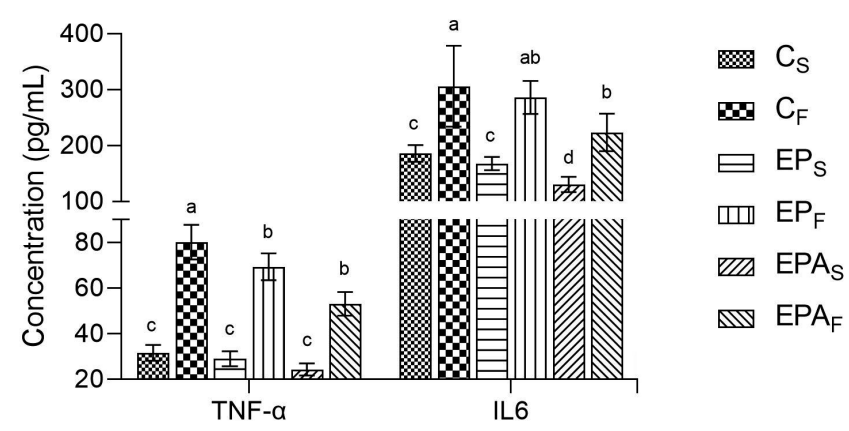

FIGURE 1. Blood serum tumor necrosis factor- $\alpha$ (TNF- $\alpha)$ and interleukin-6 (IL-6) concentrations of rats fed experimental diets: $\mathrm{C}_{\mathrm{S}}$, control diet with corn starch; $\mathrm{C}_{\mathrm{F}}$, control diet with $65 \%$ fructose; $\mathrm{EP}_{\mathrm{S}}$, corn starch diet with the strawberry fraction with ellagitannins and proanthocyanidins $(\mathrm{EP}) ; \mathrm{EP}_{\mathrm{F}}$, fructose diet with the EP fraction; $\mathrm{EPA}_{\mathrm{S}}$, corn starch diet with the strawberry fraction with ellagitannins, proanthocyanidins and anthocyanins (EPA); $\mathrm{EPA}_{\mathrm{F}}$, fructose diet with the EPA fraction. Bars with unlike letters show significantly different values $(p<0.05)$.

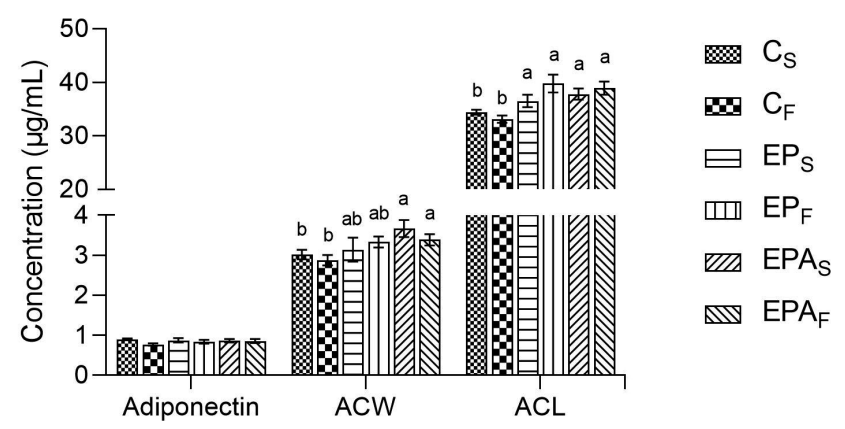

FIGURE 2. Blood serum antioxidant capacity of water-soluble (ACW), and lipid-soluble (ACL) substances, and adiponectin concentration of rats fed experimental diets: $\mathrm{C}_{\mathrm{S}}$, control diet with corn starch; $\mathrm{C}_{\mathrm{F}}$, control diet with $65 \%$ fructose; $\mathrm{EP}_{\mathrm{S}}$, corn starch diet with the strawberry fraction with ellagitannins and proanthocyanidins $(\mathrm{EP}) ; \mathrm{EP}_{\mathrm{F}}$, fructose diet with the EP fraction; $\mathrm{EPA}_{\mathrm{S}}$, corn starch diet with the strawberry fraction with ellagitannins, proanthocyanidins and anthocyanins (EPA); EPA fructose diet with the EPA extract. Bars with unlike letters show significantly different values $(p<0.05)$. 
TABLE 9. Blood serum AST and ALT activity as well as hepatic, heart, and kidneys metabolic indices of rats fed experimental diets*.

\begin{tabular}{|c|c|c|c|c|c|c|c|c|c|c|c|c|}
\hline & \multicolumn{2}{|c|}{ Serum } & \multicolumn{6}{|c|}{ Liver } & \multicolumn{2}{|c|}{ Heart } & \multicolumn{2}{|c|}{ Kidneys } \\
\hline & $\begin{array}{l}\text { AST } \\
(\mathrm{U} / \mathrm{L}) \\
\end{array}$ & $\begin{array}{l}\text { ALT } \\
(\mathrm{U} / \mathrm{L}) \\
\end{array}$ & \begin{tabular}{|c|} 
Mass \\
$(\mathrm{g} / 100 \mathrm{~g}$ BW $)$
\end{tabular} & $\begin{array}{l}\text { TBARS } \\
(\mu \mathrm{g} / \mathrm{g})\end{array}$ & $\begin{array}{c}\begin{array}{c}\text { GSH }+\mathrm{GSSG} \\
(\mu \mathrm{mol} / \mathrm{g})\end{array} \\
\end{array}$ & \begin{tabular}{|c|}
$\mathrm{GSH}$ \\
$(\mu \mathrm{mol} / \mathrm{g})$ \\
\end{tabular} & \begin{tabular}{|c|}
$\begin{array}{c}\text { GSSG } \\
(\mu \mathrm{mol} / \mathrm{g})\end{array}$ \\
\end{tabular} & $\begin{array}{l}\text { GSH/ } \\
\text { GSSG }\end{array}$ & \begin{tabular}{|c|} 
Mass \\
$(\mathrm{g} / 100 \mathrm{~g}$ BW)
\end{tabular} & $\begin{array}{c}\text { TBARS } \\
(\mu \mathrm{g} / \mathrm{g})\end{array}$ & \begin{tabular}{|c|} 
Mass \\
$(\mathrm{g} / 100 \mathrm{~g} B W)$
\end{tabular} & \begin{tabular}{|l} 
TBARS \\
$(\mu \mathrm{g} / \mathrm{g})$
\end{tabular} \\
\hline \multicolumn{13}{|c|}{ Group $n=8$} \\
\hline $\mathrm{C}_{\mathrm{s}}$ & $61.9^{\mathrm{b}}$ & $23.7^{\mathrm{b}}$ & $3.99^{\mathrm{d}}$ & 3.65 & 38.7 & 26.5 & $12.2^{\mathrm{d}}$ & $2.19^{\mathrm{a}}$ & 0.241 & 5.67 & $0.539^{c}$ & 6.69 \\
\hline $\mathrm{C}_{\mathrm{F}}$ & $83.4^{a}$ & $45.0^{\mathrm{a}}$ & $4.97^{\mathrm{a}}$ & 4.55 & 54.0 & 29.5 & $24.5^{\mathrm{a}}$ & $1.21^{\mathrm{c}}$ & 0.251 & 6.62 & $0.700^{\mathrm{a}}$ & 8.34 \\
\hline $\mathrm{EP}_{\mathrm{S}}$ & $63.4^{\mathrm{b}}$ & $27.2^{\mathrm{b}}$ & $4.02^{\mathrm{cd}}$ & 3.32 & 42.3 & 27.8 & $14.5^{\mathrm{cd}}$ & $2.01^{\mathrm{a}}$ & 0.241 & 5.83 & $0.569^{c}$ & 6.44 \\
\hline $\mathrm{EP}_{\mathrm{F}}$ & $67.1^{\mathrm{b}}$ & $29.8^{\mathrm{b}}$ & $4.89^{\mathrm{a}}$ & 4.00 & 48.1 & 27.2 & $20.9^{\mathrm{ab}}$ & $1.39^{\mathrm{bc}}$ & 0.261 & 6.39 & $0.699^{\mathrm{ab}}$ & 8.05 \\
\hline $\mathrm{EPA}_{\mathrm{s}}$ & $67.9^{\mathrm{b}}$ & $24.6^{\mathrm{b}}$ & $4.12^{\mathrm{cd}}$ & 3.20 & 46.3 & 30.4 & $15.8^{\mathrm{cd}}$ & $1.97^{\mathrm{a}}$ & 0.250 & 5.82 & $0.564^{c}$ & 6.58 \\
\hline $\mathrm{EPA}_{\mathrm{F}}$ & $64.7^{\mathrm{b}}$ & $33.5^{\mathrm{b}}$ & $4.56^{\mathrm{b}}$ & 3.73 & 50.0 & 31.3 & $18.7^{\mathrm{bc}}$ & $1.79^{\mathrm{ab}}$ & 0.252 & 6.04 & $0.633^{b}$ & 7.50 \\
\hline SEM & 1.828 & 1.595 & 0.069 & 0.097 & 1.311 & 0.799 & 0.833 & 0.082 & 0.003 & 0.099 & 0.011 & 0.169 \\
\hline \multicolumn{13}{|c|}{ Fraction $(\mathrm{F})$} \\
\hline $\mathrm{C}$ (without) & 72.6 & 34.3 & 4.48 & $4.10^{\mathrm{a}}$ & 46.4 & 28.0 & 18.4 & 1.70 & 0.246 & 6.14 & 0.619 & 7.51 \\
\hline EP & 65.3 & 65.3 & 4.45 & $3.66^{\mathrm{b}}$ & 45.2 & 27.5 & 17.7 & 1.70 & 0.251 & 6.11 & 0.619 & 7.25 \\
\hline EPA & 67.2 & 67.2 & 4.29 & $3.48^{\mathrm{b}}$ & 47.9 & 30.6 & 17.3 & 1.85 & 0.253 & 5.97 & 0.600 & 7.04 \\
\hline$p$ value & 0.155 & 0.139 & 0.056 & 0.007 & 0.641 & 0.268 & 0.803 & 0.585 & 0.415 & 0.732 & 0.429 & 0.407 \\
\hline \multicolumn{13}{|c|}{ Diet type (T) } \\
\hline Starch & 65.0 & 25.2 & 4.01 & $3.40^{\mathrm{b}}$ & $42.3^{b}$ & 28.0 & 14.2 & 2.04 & 0.245 & $5.80^{\mathrm{b}}$ & 0.559 & $6.57^{\mathrm{b}}$ \\
\hline FRU & 71.7 & 36.1 & 4.81 & $4.10^{\mathrm{a}}$ & $50.7^{\mathrm{a}}$ & 29.3 & 21.4 & 1.46 & 0.255 & $6.35^{\mathrm{a}}$ & 0.667 & $7.96^{\mathrm{a}}$ \\
\hline$p$ value & 0.041 & $* *$ & $* *$ & $* *$ & 0.001 & 0.425 & $* *$ & $* *$ & 0.054 & 0.005 & $* *$ & $* *$ \\
\hline \multicolumn{13}{|c|}{ Interaction $\mathrm{F} \times \mathrm{T}$} \\
\hline$p$ value & 0.006 & 0.017 & 0.032 & 0.593 & 0.121 & 0.647 & 0.012 & 0.048 & 0.174 & 0.205 & 0.020 & 0.501 \\
\hline
\end{tabular}

${ }^{*} \mathrm{C}_{\mathrm{S}}$, control diet with corn starch; $\mathrm{C}_{\mathrm{F}}$ control diet with $65 \%$ fructose $(\mathrm{FRU}) ; \mathrm{EP}_{\mathrm{S}}$, corn starch diet with the strawberry fraction with ellagitannins and proanthocyanidins $(\mathrm{EP}) ; \mathrm{EP}_{\mathrm{F}}$, fructose diet with the $\mathrm{EP}$ fraction; $\mathrm{EPA}_{\mathrm{s}}$, corn starch diet with the strawberry fraction with ellagitannins, proanthocyanidins and anthocyanins $(\mathrm{EPA}) ; \mathrm{EPA}_{\mathrm{F}}$ fructose diet with the EPA fraction.

a,b,c Mean values within a column with unlike superscript letters were shown to be significantly different $(p<0.05)$; differences among the groups $\mathrm{C}_{\mathrm{S}}$, $\mathrm{C}_{\mathrm{F}}, \mathrm{EP}_{\mathrm{S}}, \mathrm{EP}_{\mathrm{F}}, \mathrm{EPA}_{\mathrm{S}}$, and $\mathrm{EPA}_{\mathrm{F}}$ were indicated with superscripts only in the case of a statistically significant interaction $\mathrm{F} \times \mathrm{T}(p<0.05)$ and in that case the differences for the main factors $\mathrm{F}$ and $\mathrm{T}$ are not shown. ${ }^{* *} p<0.001$. ALT, alanine transaminase; AST, aspartate transaminase; TBARS, thiobarbituric acid reactive substances; GSH, reduced glutathione; GSSG, oxidized glutathione; BW, body weight.

berries. Urolithins (A, C, D), which are metabolites of ETs, favorably change the concentration of triglycerides and fatty acid oxidation in adipocytes and liver cells, as demonstrated by Kang et al. [2016].

Unfavorable changes in liver, kidney, and heart parameters were noted in our study with the high-fructose diet. A significant $\mathrm{F} \times \mathrm{T}$ interaction showed that, among all experimental groups, the highest hepatic TC and TG concentrations as well as blood serum AST and ALT activities were found in the $\mathrm{C}_{\mathrm{F}}$ group $(p<0.05 v s$. all other groups; Table 9 and Figure 3). The highest concentration of hepatic GSSG was noted in the $\mathrm{C}_{\mathrm{F}}$ group $(p<0.05$ vs. remaining groups except $\mathrm{EP}_{\mathrm{F}}$; see: interaction $\mathrm{F} \times \mathrm{T}$ ). As a result, the lowest value of GSH/GSSG ratio followed the consumption of the $\mathrm{C}_{\mathrm{F}}$ diet $\left(p<0.05 v\right.$ s. remaining groups except $\mathrm{EP}_{\mathrm{F}}$; interaction $\left.\mathrm{F} \times \mathrm{T}\right)$. The two-way ANOVA showed that, irrespective of fraction addition, the fructose treatment significantly decreased the hepatic expression of PPAR $\alpha$ (Figure 4), increased hepatic TBARS and total glutathione concentrations as well as increased TBARS concentrations in heart and kidney tissues in comparison to the starch treatment. When the fraction addition is considered regardless of diet type, both EP and EPA dietary fractions significantly increased the expression of PPAR $\alpha$ and decreased TBARS concentration in the liver tissue $(p<0.05 v s$. C). The addition of EPA to the high-fructose diet more favorably reduced the increase in liver and kidney mass, as well as GSH/GSSG ratio in the liver than the fraction without anthocyanins, which corresponds to the research hypothesis. Regardless ACs presence in the preparation, both strawberry fractions reduced lipid peroxidation and pro-inflammatory processes in the liver. Long-term and high-fructose diet consumption results in non-normative lipid accumulation in the liver and liver weight gain. Moreover, excessive fructose intake promotes glucose metabolism disorders and oxidative stress, which correlate with the possibility of liver damage [Lu et al., 2020]. The metabolites of strawberry polyphenols, formed as a result of microbiological biotransformation in the intestine, are largely metabolized in the liver, and liver 


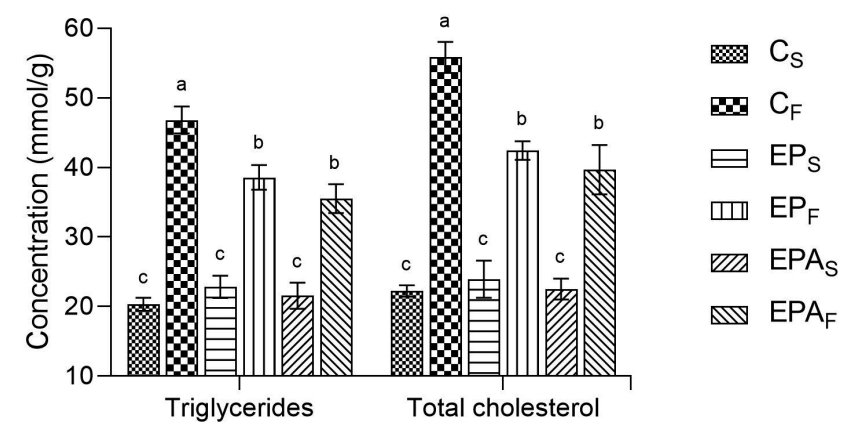

FIGURE 3. Liver triglyceride and total cholesterol concentrations of rats fed experimental diets: $\mathrm{C}_{\mathrm{S}}$, control diet with corn starch; $\mathrm{C}_{\mathrm{F}}$ control diet with $65 \%$ fructose; $\mathrm{EP}_{\mathrm{S}}$, corn starch diet with the strawberry fraction with ellagitannins and proanthocyanidins $(\mathrm{EP}) ; \mathrm{EP}_{\mathrm{F}}$ fructose diet with the $\mathrm{EP}$ fraction; $\mathrm{EPA}_{\mathrm{s}}$, corn starch diet with the strawberry fraction with ellagitannins, proanthocyanidins and anthocyanins (EPA); $\mathrm{EPA}_{\mathrm{F}}$ fructose diet with the EPA fraction. Bars with unlike letters show significantly different values $(p<0.05)$.

functions could be modified under the influence of polyphenol metabolic derivatives. In the Elkhadragy \& Abdel Moneim [2017] study, the strawberry ethanolic extract significantly alleviated adverse changes in liver function in rats administered hepatotoxic cadmium chloride. Anthocyanin-rich extract from $F$. ananassa effectively lowered cadmium accumulation in the liver, increased the activity of antioxidant enzymes, including superoxide dismutase (SOD), catalase (CAT), GSH peroxidase and GSH reductase, inhibited lipid peroxidation processes, lowered the content of nitric oxide (NO) in the liver, and reduced the apoptosis of hepatocytes. In the acrylamidetreated mice, adverse changes in the activity of antioxidant enzymes in the liver and destruction of hepatocyte DNA were mitigated by a diet supplemented with freeze-dried strawberries [Zhao et al., 2015]. Strawberry preparations rich in ETs investigated in the experiment of Fotschki et al. [2018] with rats fed a fructose-rich diet also caused beneficial changes in the liver GSSG concentration and the desired increase in the GSH/ GSSG ratio.

The application of fructose and strawberry fractions in the experimental diets did not significantly affect the hematological parameters of rats' blood, except for the erythrocyte volumetric variability index $(\mathrm{RDWc})$, whose value increased significantly when the diet was loaded with fructose (data not shown). RDW corresponds to anisocytosis, a factor that indicates the variability of the red blood cell volume distribution. Recent studies have indicated that the RDW can be used as a laboratory parameter in such diseases as prostate cancer, inflammatory bowel diseases, and cardiovascular diseases [Cheng et al., 2017]. The RDW is now a commonly used laboratory marker of an inflammatory condition in the body. An elevated anisocytosis may indicate anemia caused by iron deficiency. According to the latest research with rats [Wang et al., 2021], a high-fructose diet causes systemic iron deficiency and hepatic iron overload possibly as a result of activation of a pro-inflammatory state, which may explain the increase in RDW in the fructose groups in our study.

Irrespective of fraction addition, the fructose treatment significantly reduced the cecal concentration of nasutin A and urinal concentration of nasutin A glucuronide,

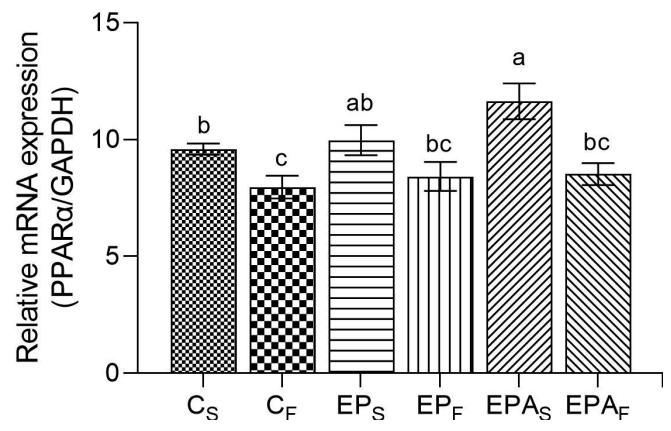

FIGURE 4. Hepatic peroxisome proliferator-activated receptor $\alpha$ (PPAR $\alpha)$ expression of rats fed experimental diets: $\mathrm{C}_{\mathrm{S}}$, control diet with corn starch; $\mathrm{C}_{\mathrm{F}}$ control diet with $65 \%$ fructose; $\mathrm{EP}_{\mathrm{S}}$, corn starch diet with the strawberry fraction with ellagitannins and proanthocyanidins $(\mathrm{EP}) ; \mathrm{EP}_{\mathrm{F}}$, fructose diet with the EP extract; $\mathrm{EPA}_{\mathrm{S}}$, corn starch diet with the strawberry fraction with ellagitannins, proanthocyanidins and anthocyanins (EPA); $\mathrm{EPA}_{\mathrm{F}}$ fructose diet with the EPA extract. Bars with unlike superscript letters show significantly different values $(p<0.05)$.

in comparison to the starch treatment (Figure 5). Considering dietary fraction addition, the EPA treatment excelled the EP one in cecal nasutin $\mathrm{A}$ and urinal nasutin A glucuronide concentrations $(p<0.05)$. A high-fructose diet leads to changes in the intestinal microflora, which to a large extent determines the qualitative and quantitative composition of polyphenol metabolites in intestinal digesta and body fluids. Milala et al. [2017] have indicated NS to be the main metabolite in the digestive tract and in the faces, blood serum, and urine of rats fed a diet with ET-rich strawberry extracts. NSs, as well as other metabolites of ETs, such as UTs, are believed to elicit anti-inflammatory, antioxidant, chemopreventive, and anti-carcinogenic effects [Stanisławska et al., 2016]. Mazzone et al. [2013] have demonstrated a strong antioxidant effect of nasutin A in a study using density functional theories across three different response mechanisms: hydrogen atom transfer (HAT), electron transfer followed by proton transfer (SET-PT), and sequential proton loss electron transfer (SPLET). In the study by Stanisławska et al. [2016], nasutin A inhibited the proliferation of prostate cancer cells in vitro. In the discussed studies, the fructose diet adversely

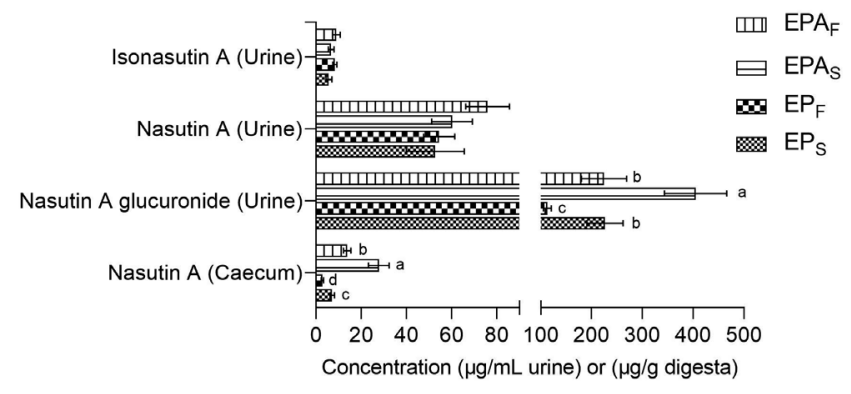

FIGURE 5. Ellagitannins' metabolite concentrations in the caecal digesta and in the urine of rats fed experimental diets: $\mathrm{EP}_{\mathrm{S}}$, corn starch diet with the strawberry fraction with ellagitannins and proanthocyanidins $(\mathrm{EP}) ; \mathrm{EP}_{\mathrm{F}}$, fructose diet with the $\mathrm{EP}$ fraction; $\mathrm{EPA}_{\mathrm{S}}$, corn starch diet with the strawberry fraction with ellagitannins, proanthocyanidins and anthocyanins (EPA); $\mathrm{EPA}_{\mathrm{F}}$, fructose diet with the EPA fraction. Bars with unlike superscript letters were show significantly different values $(p<0.05)$. 
affected the cecal concentration of nasutin A and urinal concentration of nasutin A glucuronide. According to the research hypothesis, the presence of ACs in the EPA fraction probably limited the adverse impact of the high-fructose diet on the intestinal microflora, and thus on the processes of polyphenol transformation by the beneficial intestinal microbiome, which resulted in higher concentrations of nasutin A and nasutin A glucuronide in rats' cecum and urine in the EPA groups.

\section{CONCLUSIONS}

To sum up, the high-fructose diet administered to rats in this study led to disorders in their gastrointestinal tract and adverse changes in the antioxidant and pro-inflammatory status of their bodies, as well as in their liver and lipid metabolism. Nevertheless, the addition of strawberry EP fraction, containing mostly ellagitannins and proanthocyanidins, mitigated the negative effects of consuming the high-fructose diet, like the reduction in $\mathrm{TC}$ and $\mathrm{TG}$ and the increase in ACW and ACL in blood serum. Interestingly, the EPA fraction containing anthocyanins more distinctly alleviated the negative effects of consuming excess fructose in the diet, as manifested by a decreased serum IL-6 concentration, atherogenicity index $\lg (\mathrm{TG} / \mathrm{HDL})$ and hepatic GSSG as well as by an increased serum level of ACW and hepatic GSH/GSSG ratio. Part of these effects can be probably attributed to the increased activity of cecal microbiota leading to higher concentrations of cecal SCFAs and urinal bioactive ellagitannin metabolites. The biotransformation of anthocyanins by the intestinal microbiota probably intensified the beneficial effects of the EPA fraction. However, the metabolism of phenolic compounds, including ACs and ETs, depends on many factors, including both the species- and the individual-specific ones. Future studies need to be conducted with other experimental models, including especially human trials.

\section{RESEARCH FUNDING}

This research was supported by statutory funds from the Department of Biological Functions of Food, Institute of Animal Reproduction and Food Research, Polish Academy of Sciences, Olsztyn, Poland; and Department of Microbiology and Food Technology, Faculty of Agriculture and Biotechnology, University of Science and Technology, Bydgoszcz, Poland.

\section{CONFLICTS OF INTEREST}

The authors declare no conflict of interest.

\section{ORCID IDs}

B. Fotschki https://orcid.org/0000-0002-9727-7481 J. Juśkiewicz https://orcid.org/0000-0003-0068-5970 M. Kosmala https://orcid.org/0000-0002-9018-3028 P. Matusevicius https://orcid.org/0000-0002-6612-2479 J. Milala https://orcid.org/0000-0002-4732-1907 E. Żary-Sikorska https://orcid.org/0000-0001-8140-3861

\section{REFERENCES}

1. Aboonabi, A., Aboonabi, A. (2020). Anthocyanins reduce inflammation and improve glucose and lipid metabolism associated with inhibiting nuclear factor-kappaB activation and increasing PPAR- $\gamma$ gene expression in metabolic syndrome subjects. Free Radical Biology and Medicine, 150, 30-39.

https://doi.org/10.1016/j.freeradbiomed.2020.02.004

2. AOAC, Official Methods of Analysis, 21st Edition - AOAC International. 2019. Available online: [https://www.aoac.org/officialmethods-of-analysis-21st-edition-2019] (accessed 23 June 2020).

3. Aura, A.M., Martin-Lopez, P., O'Leary, K.A., Williamson, G., Oksman-Caldentey, K.-M., Poutanen, K., Santos-Buelga, C. (2005). In vitro metabolism of anthocyanins by human gut microflora. European Journal of Nutrition, 44(3), 133-142.

https://doi.org/10.1007/s00394-004-0502-2

4. Awolade, P., Cele, N., Kerru, N., Gummidi, L., Oluwakemi, E., Singh, P. (2020). Therapeutic significance of $\beta$-glucuronidase activity and its inhibitors: A review. European Journal of Medicinal Chemistry, 187, art. no. 111921.

https://doi.org/10.1016/j.ejmech.2019.111921

5. Bauza-Kaszewska, J., Żary-Sikorska, E., Gugolek, A., Ligocka, A., Kosmala, M., Karlińska, E., Fotschki, B., Juśkiewicz, J. (2021). Synergistic antimicrobial effect of raspberry (Rubus idaeus L., Rosaceae) preparations and probiotic bacteria on enteric pathogens. Polish Journal of Food and Nutrition Sciences, 71 (1), 51-59. https://doi.org/10.31883/pjfns/132897

6. Bialonska, D., Ramnani, P., Kasimsetty, S.G., Muntha, K.R., Gibson, G.R., Ferreira, D. (2010). The influence of pomegranate by-product and punicalagins on selected groups of human intestinal microbiota. International Journal of Food Microbiology, 140(2-3), 175-182.

https://doi.org/10.1016/j.ijfoodmicro.2010.03.038

7. Botsoglou, N.A., Fletouris, D.J., Papageorgiou, G.E., Vassilopoulos, V.N., Mantis, A.J., Trakatellis, A.G. (1994). Rapid, sensitive, and specific thiobarbituric acid method for measuring lipid peroxidation in animal tissue, food and feedstuff samples. Journal of Agricultural and Food Chemistry, 42 (9), 1931-1937.

https://doi.org/10.1021/jf00045a019

8. Buzzini, P., Arapitsas, P., Goretti, M., Branda, E., Turchetti, B., Pinelli, P., Ieri, F., Romani, A. (2008). Antimicrobial and antiviral activity of hydrolysable tannins. Mini-Reviews in Medicinal Chemistry, 8(12), 1179-1187.

https://doi.org/10.2174/138955708786140990

9. Cheng, S., Han, F., Wang, Y., Xu, Y., Qu, T., Ju, Y., Lu, Z. (2017). The red distribution width and the platelet distribution width as prognostic predictors in gastric cancer. BMC Gastroenterology, 17(1), art. no. 163. https://doi.org/10.1186/s12876-017-0685-7

10. DeBosch, B.J., Chen, Z., Finck, B.N., Chi, M., Moley, K.H. (2013). Glucose transporter-8 (GLUT8) mediates glucose intolerance and dyslipidemia in high-fructose diet-fed male mice. Molecular Endocrinology, 27(11), 1887-1896.

https://doi.org/10.1210/me.2013-1137

11. Elkhadragy, M.F., Abdel Moneim, A.E. (2017). Protective effect of Fragaria ananassa methanolic extract on cadmium chloride $(\mathrm{CdCl} 2)$-induced hepatotoxicity in rats. Toxicology Mechanisms and Methods, 27(5), 335-345.

https://doi.org/10.1080/15376516.2017.1285973 
12. EU Directive (2010/63/EU). Directive 2010/63/EU of the European Parliament and of the Council of 22 September 2010 on the protection of animals used for scientific purposes.

13. Ertan, K., Türkyılmaz, M., Özkan, M. (2020). Color and stability of anthocyanins in strawberry nectars containing various co-pigment sources and sweeteners. Food Chemistry, 310, art. no. 125856.

https://doi.org/10.1016/j.foodchem.2019.125856

14. Folch, J., Lees, M., Sloane Stanley, G.H. (1957). A simple method for the isolation and purification of total lipids from animal tissues. Journal of Biological Chemistry, 226(1), 497-509. https://doi.org/10.1016/S0021-9258(18)64849-5

15. Forbes-Hernández, T.Y., Gasparrin, M., Afrin, S., Cianciosi, D., González-Paramás, A.M., Santos-Buelga, C., Mezzetti, B., Quiles, J.L., Battino, M., Giampieri, F., Bompadre, S. (2017). Strawberry (cv. Romina) methanolic extract and anthocyanin-enriched fraction improve lipid profile and antioxidant status in HepG2 cells. International Journal of Molecular Sciences, 18(6), art. no. 1149 .

https://doi.org/10.3390/ijms18061149

16. Fotschki, B., Milala, J., Jurgoński, A., Karlińska, E., Zduńczyk, Z., Juśkiewicz, J. (2014). Strawberry ellagitannins thwarted the positive effects of dietary fructooligosaccharides in rat cecum. Journal of Agricultural and Food Chemistry, 62 (25), 5871-5880. https://doi.org/10.1021/jf405612a

17. Fotschki, B., Juśkiewicz, J., Jurgoński, A., Kołodziejczyk, K., Milala, J., Kosmala, M., Zduńczyk, Z. (2016). Anthocyanins in strawberry polyphenolic extract enhance the beneficial effects of diets with fructooligosaccharides in the rat cecal environment. PLOS ONE, 11 (2), art. no. e0149081.

https://doi.org/10.1371/journal.pone.0149081

18. Fotschki, B., Juśkiewicz, J., Kołodziejczyk, K., Jurgoński, A., Kosmala, M., Milala, J., Ognik, K., Zduńczyk, Z. (2018). Protective effects of ellagitannin-rich strawberry extracts on biochemical and metabolic disturbances in rats fed a diet high in fructose. Nutrients, 10(4), art. no. 445.

https://doi.org/10.3390/nu10040445

19. Fuke, N., Nagata, N., Suganuma, H., Ota, T. (2019). Regulation of gut microbiota and metabolic endotoxemia with dietary factors. Nutrients, 11(10), art. no. 2277.

https://doi.org/10.3390/nu11102277

20. Giampieri, F., Tulipani, S., Alvarez-Suarez, J.M., Quiles, J.L., Mezzetti, B., Battino, M. (2012). The strawberry: Composition, nutritional quality, and impact on human health. Nutrition, 28(1), 9-19.

https://doi.org/10.1016/j.nut.2011.08.009

21. Gonzalez-Barrio, R., Truchado P., Ito, H., Espín, J.C., Tomas-Barberan, F. (2011). UV and MS identification of urolithins and nasutins, the bioavailable metabolites of ellagitannins and ellagic acid in different mammals. Journal of Agricultural and Food Chemistry, 59(4), 1152-1162.

https://doi.org/10.1021/jf103894m

22. Hambly, R.J., Rumney, C.J., Cunningham, M., Fletcher, J.M.E., Rijken, P., Rowland, I.R. (1997). Influence of diets containing high and low risk factors for colon cancer on early stages of carcinogenesis in human-flora-associated (HFA) rats. Carcinogenesis, 18(8), 1535-1539.

https://doi.org/10.1093/carcin/18.8.1535
23. Hassimotto, N., Moreira, V., Nascimento, N., Souto, P., Teixeira, C., Lajolo, F.M. (2013). Inhibition of carrageenan-induced acute inflammation in mice by oral administration of anthocyanin mixture from wild mulberry and cyanidin-3-glucoside. BioMed Research International, 2013, art. no. 146716.

https://doi.org/10.1155/2013/146716

24. Hidalgo, M., Oruna-Concha, M.J., Kolida, S., Walton, G.E., Kallithraka, S., Spencer, J.P.E., Gibson, G.R., de Pascual-Teresa, S. (2012). Metabolism of anthocyanins by human gut microflora and their influence on gut bacterial growth. Journal of Agricultural and Food Chemistry, 60(15), 3882-3890.

https://doi.org/10.1021/jf3002153

25. Hillilä, M., Färkkilä, M.A., Sipponen, T., Rajala, J., Koskenpato, J. (2016). Does oral galactosidase relieve irritable bowel symptoms?. Scandinavian Journal of Gastroenterology, 51 (1), 16-21. https://doi.org/10.3109/00365521.2015.1063156

26. Horne, R.G., Yu, Y., Zhang, R., Abdalqadir, N., Rossi, L., Surette, M., Sherman, P.M., Adeli, K. (2020). High fat-high fructose diet-induced changes in the gut microbiota associated with dyslipidemia in Syrian hamsters. Nutrients, 12(11), art. no. 3557.

https://doi.org/10.3390/nu12113557

27. Jarosławska, J., Juśkiewicz, J., Wróblewska, M., Jurgoński, A., Król, B., Zduńczyk, Z. (2011). Polyphenol-rich strawberry pomace reduces serum and liver lipids and alters gastrointestinal metabolite formation in fructose-fed rats. Journal of Nutrition, 141(10), 1777-1783.

https://doi.org/10.3945/jn.111.143677

28. Jurgoński, A., Juśkiewicz, J., Zduńczyk, Z. (2013). An anthocyanin-rich extract from Kamchatka honeysuckle increases enzymatic activity within the gut and ameliorates abnormal lipid and glucose metabolism in rats. Nutrition, 29(6), 898-902.

https://doi.org/10.1016/j.nut.2012.11.006

29. Kang, I., Kim, Y.E., Tomás-Barberán, F.A., Espín, J.C., Chung, S. (2016). Urolithin A, C, and D, but not iso-urolithin A and urolithin B, attenuate triglyceride accumulation in human cultures of adipocytes and hepatocytes. Molecular Nutrition and Food Research, 60(5), 1129-1138.

https://doi.org/10.1002/mnfr.201500796

30. Kennedy, J.A., Jones, G.P. (2001). Analysis of proanthocyanidin cleavage products following acid-catalysis in the presence of excess phloroglucinol. Journal of Agricultural and Food Chemistry, 49(4), 1740-1746. https://doi.org/10.1021/jf001030o

31. Kosmala, M., Zduńczyk, Z., Juśkiewicz, J., Jurgoński, A., Karlińska, E., Macierzyński, J., Jańczak, R., Rój, E. (2015). Chemical composition of defatted strawberry and raspberry seeds and the effect of these dietary ingredients on polyphenol metabolites, intestinal function, and selected serum parameters in rats. Journal of Agricultural and Food Chemistry, 63(11), 2989-2996.

https://doi.org/10.1021/acs.jafc.5b00648

32. Liu, C.J., Lin, J.Y. (2013). Anti-inflammatory effects of phenolic extracts from strawberry and mulberry fruits on cytokine secretion profiles using mouse primary splenocytes and peritoneal macrophages. International Immunopharmacology, 16(2), 165-170.

https://doi.org/10.1016/j.intimp.2013.03.032 
33. Loke, Y.L., Chew, M.T., Ngeow, Y.F., Lim, W.W.D., Peh, S.C. (2020). Colon carcinogenesis: the interplay between diet and gut microbiota. Frontiers in Cellular and Infection Microbiology, 10, art. no. 603086.

https://doi.org/10.3389/fcimb.2020.603086

34. Lu, Y., Wu, Y., Chen, X., Yang, X., Xiao, H. (2020). Water extract of shepherd's purse prevents high-fructose induced-liver injury by regulating glucolipid metabolism and gut microbiota. Food Chemistry, 16(342), art. no. 128536.

https://doi.org/10.1016/j.foodchem.2020.128536

35. Markowiak-Kopeć, P., Śliżewska, K. (2020). The effect of probiotics on the production of short-chain fatty acids by human intestinal microbiome. Nutrients, 12(4), art. no. 1107.

https://doi.org/10.3390/nu12041107

36. Mazzone, G., Marirosa, T., Nino, R. (2013). Density functional predictions of antioxidant activity and UV spectral features of nasutin a, isonasutin, ellagic acid, and one of its possible derivatives. Journal of Agricultural and Food Chemistry, 61(40), 9650-9657.

https://doi.org/10.1021/jf403262k

37. Milala, J., Kosmala, M., Karlińska, E., Juśkiewicz, J., Zduńczyk, Z., Fotschki, B. (2017). Ellagitannins from strawberries with different degree of polymerization showed different metabolism through gastrointestinal tract of rats. Journal of Agricultural and Food Chemistry, 65(49), 10738-10748.

https://doi.org/10.1021/acs.jafc.7b04120

38. Molan, A.L., Liu, Z., Kruger, M. (2010). The ability of blackcurrant extracts to possitively modulate key markers of gastrointestinal function in rats. World Journal of Microbiology and Biotechnology, 26(10), 1735- 1743.

https://doi.org/10.1007/s11274-010-0352-4

39. Mizobe, T., Nakajima, Y., Ueno, H., Sessler, D.I. (2006). Fructose administration increases intraoperative core temperature by augmenting both metabolic rate and the vasoconstriction threshold. Anesthesiology, 104(6), 1124-1130. https://doi.org/10.1097/00000542-200606000-00005

40. Nowicka, A., Kucharska, A.Z., Sokót-Łętowska, A., Fecka, I. (2019). Comparison of polyphenol content and antioxidant capacity of strawberry fruit from 90 cultivars of Fragariaananassa Duch. Food Chemistry, 270, 32-46.

https://doi.org/10.1016/j.foodchem.2018.07.015

41. Park, G., Jung, S., Wellen, K.E., Jang, Ch. (2021). The interaction between the gut microbiota and dietary carbohydrates in nonalcoholic fatty liver disease. Experimental \& Molecular Medicine, 53, 809-822. https://doi.org/10.1038/s12276-021-00614-x

42. Prior, R.L., Wu, X., Gu, L., Hager, T., Hager, A., Wilkes, S., Howard, L. (2009). Purified berry anthocyanins but not whole berries normalize lipid parameters in mice fed an obesogenic high fat diet. Molecular Nutrition and Food Research, 53(11), 1406-1418. https://doi.org/10.1002/mnfr.200900026

43. Rahman, I., Kode, A., Biswas, S.K. (2006). Assay for quantitative determination of glutathione and glutathione disulfide levels using enzymatic recycling method. Nature Protocols, 1(6), 3159-3165.

https://doi.org/10.1038/nprot.2006.378
44. Reagan-Shaw, S., Nihal, M., Ahmad, N. (2008.) Dose translation from animal to human studies revisited. The FASEB Journal, 22(3), 659-661.

https://doi.org/10.1096/fi.07-9574LSF

45. Reeves, P.G. (1997). Components of the AIN-93 diets as improvements in the AIN-76A diet. Journal of Nutrition, 127(5), 838S-841S.

https://doi.org/10.1093/jn/127.5.838S

46. Selma, M.V., Beltrán, D., García-Villalba, R., Espín, J.C., TomásBarberán, F.A. (2014). Description of urolithin production capacity from ellagic acid of two human intestinal Gordonibacter species. Food and Function, 5(8), 1779-1784.

https://doi.org/10.1039/C4FO00092G

47. Sirijan, M., Pipattanawong, N., Saeng-on, B., Chaiprasart, P. (2020). Anthocyanin content, bioactive compounds and physico-chemical characteristics of potential new strawberry cultivars rich in-anthocyanins. Journal of Berry Research, 10(3), 397-410. https://doi.org/10.3233/JBR190487

48. Sójka, M., Klimczak, E., Macierzyński, J., Kołodziejczyk, K. (2013). Nutrient and polyphenolic composition of industrial strawberry press cake. European Food Research and Technology, 237(6), 995-1007.

https://doi.org/10.1007/s00217-013-2070-2

49. Stanisławska, I.J., Granica, S., Piwowarski, J.P., Szawkało, J., Wiązecki, K., Czarnocki, Z., Kiss A.K. (2016). 5-(3',4',5'-trihydroxyphenyl)- $\gamma$-valerolactone and nasutin A inhibit LNCaP prostate cancer cell proliferation. Planta Medica, 82(S01), S1-S381.

https://doi.org/10.1055/s-0036-1596836

50. Tappy, L., Lê, K.A., (2010). Metabolic effects of fructose and the worldwide increase in obesity. Physiological Reviews, 90(1), 23-46.

https://doi.org/10.1152/physrev.00019.2009

51. Wang, Ch., Wang, X., Song, G., Xing, H., Linquan, Y., Han, K., Chang, Y-Z. (2021). A high-fructose diet in rats induces systemic iron deficiency and hepatic iron overload by an inflammation mechanism. Journal of Food Biochemistry, 45(1), art. no. e13578. https://doi.org/10.1111/jfbc.13578

52. Xu, J., Yuan, Ch., Wang, G., Ma, H., Jiaming L., Xu, L., Li, L., Seeram N.P., Huang X., Mu, Y., Li, Y. (2018). Urolithins attenuate LPS-induced neuroinflammation in BV2Microglia via MAPK, Akt, and NF-кB signaling pathways. Journal of Agricultural and Food Chemistry, 66(3), 571-580.

https://doi.org/10.1021/acs.jafc.7b03285

53. Zduńczyk, Z., Juśkiewicz, J., Estrella, I. (2006). Caecal parameters of rats fed diets containing grapefruit polyphenols and inulin as single supplements or in a combination. Nutrition, 22(9), 898-904.

https://doi.org/10.1016/j.nut.2006.05.010

54. Zhao, M., Liu, X., Luo, Y., Guo, H., Hu, X., Chen, F. (2015). Evaluation of protective effect of freeze-dried strawberry, grape, and blueberry powder on acrylamide toxicity in mice. Journal of Science, 80(4), H869-H874.

https://doi.org/10.1111/1750-3841.12815

55. Żary-Sikorska, E., Fotschki, B., Fotschki, J., Wiczkowski, W., Juśkiewicz, J. (2019). Preparations from purple carrots contain- 
ing anthocyanins improved intestine microbial activity, serum lipid profile and antioxidant status in rats. Journal of Functional Foods, 60, art. no. 103442.

https://doi.org/10.1016/j.jf.2019.103442

56. Żary-Sikorska, E., Fotschki, B., Jurgoński, A., Kosmala, M., Milala, J., Kołodziejczyk, K., Majewski, M., Ognik, K., Juśkiewicz, J.
(2020). Protective effects of a strawberry ellagitannin-rich extract against pro-oxidative and pro-inflammatory dysfunctions induced by a high-fat diet in a rat model. Molecules, 25(24), art. no. 5874 .

https://doi.org/10.3390/molecules25245874 